\title{
П. В.Западалова
}

\section{ИКОНА “СВЯТАЯ ТРОИЦА СО СЦЕНАМИ БЫТИЯ» ИЗ ТРОИЦЕ-ГЛЕДЕНСКОГО МОНАСТЫРЯ}

Государственный Русский музей,

Российская Федерация, 191186, Санкт-Петербург, Инженерная ул., 4

Статья представляет собой анализ стиля иконы второй половины XVII в. «Святая Троица со сценами Бытия» из Троице-Гледенского монастыря. Рассматривается история ее изучения, вводятся в научный оборот сведения из архивных документов XVIII-XIX вв., подтверждающие, что некогда образ был храмовым, размещался рядом с царскими вратами Троицкого собора и лишь позднее при строительстве нового иконостаса был перенесен в киот на южной стене храма. При исследовании стиля произведения автор пришла к заключению о его большой близости иконам 50-х - начала 60-х годов XVII в. кисти прославленного мастера Федора Зубова. В статье заостряется внимание на чертах сходства. Впервые указываются некоторые изобразительные источники, использовавшиеся иконописцем при создании иконы (листы, иллюстрирующие историю Авраама, из Библии Пискатора). Определяются основные признаки придворного иконописания «доушаковского» периода середины XVII в., высказывается мнение о принадлежности «Святой Троицы», как и всего раннего творчества Федора Зубова, данному стилистическому течению. Библиогр. 55 назв. Ил. 29.

Ключевые слова: икона «Святая Троица со сценами Бытия», Троице-Гледенский монастырь, Великий Устюг, середина XVII в., Федор Зубов, церковь Ильи Пророка в Ярославле, Библия Пискатора, «роскошный» стиль.

\section{P. V.Zapadalova \\ “THE HOLY TRINITY AND SCENES FROM THE BOOK OF GENESIS”. ICON FROM THE TROITSE-GLEDENSKY MONASTERY}

\section{State Russian Museum, 4, Inzhenernaya str., St. Petersburg, 191186, Russian Federation}

The article concerns some stylistic features of the $17^{\text {th }}$ century icon of the "Holy Trinity" from the Troitse-Gledensky monastery near Veliky Ustyug. The author examines other meanings devoted to this image and also tells about some new early documentation which containing information about it. They prove, that it was in the past an extremely important icon of the Trinity cathedral. Investigating its style, the author identifies the closest stylistic analogies as the icons created by the famous Russian painter Fiodor Zubov from the late 1750s to the early 1760s. New iconographic sources of the icon are named for the first time. The early work of Fiodor Zubov and "Holy Trinity" are considered as belonging to the official "luxurious" style of Russian painting. Refs. 55. Figs 29.

Keywords: Icon, Holy Trinity, Genesis Scenes, Feodor Zubov, St. Elias Church in Yaroslavl, "luxurious" style, Troitse-Gledensky monastery, middle of the $17^{\text {th }}$ century, Veliky Ustyug.

Троицкий Гледенский мужской монастырь находится на правой стороне р. Сухоны, ниже г. Устюга, в двух с половиной верстах, на высокой горе, исстари называемой Гледеном $[1$, с. 35].

В каменном соборном храме Троице-Гледенского монастыря, на правой стене, в золоченом резном киоте «в заворот» местного ряда иконостаса находится in situ огромный образ Ветхозаветной Троицы ${ }^{1}$, который по праву может считаться

1 Свою благодарность нам бы хотелось выразить О.А. Малковой, Н.Н.Буторовой (ВУМЗ), Н.И. Комашко (МиАР), Н.В.Пивоваровой и И.Д.Соловьевой (ГРМ). Материалы были подготовлены к конференции памяти В.М. Сорокатого (МиАР, март 2015), некогда работавшего с архивом Троицкого Гледенского монастыря и поднимавшего тему великоустюгского иконописания в своих работах [2, с. 181-192].

(c) Санкт-Петербургский государственный университет, 2017 
самым ярким произведением иконописи, связанным своим происхождением с этой обителью (рис. 1)². Оно неоднократно публиковалось. В каталоге 1998 г. «Возрожденные шедевры Русского Севера» в качестве его датировки указана вторая половина XVII в. А.А.Рыбаков, рассматривая во вступительной статье иконы из Гледенского монастыря, усматривал влияние на их стиль строгановской школы ико-

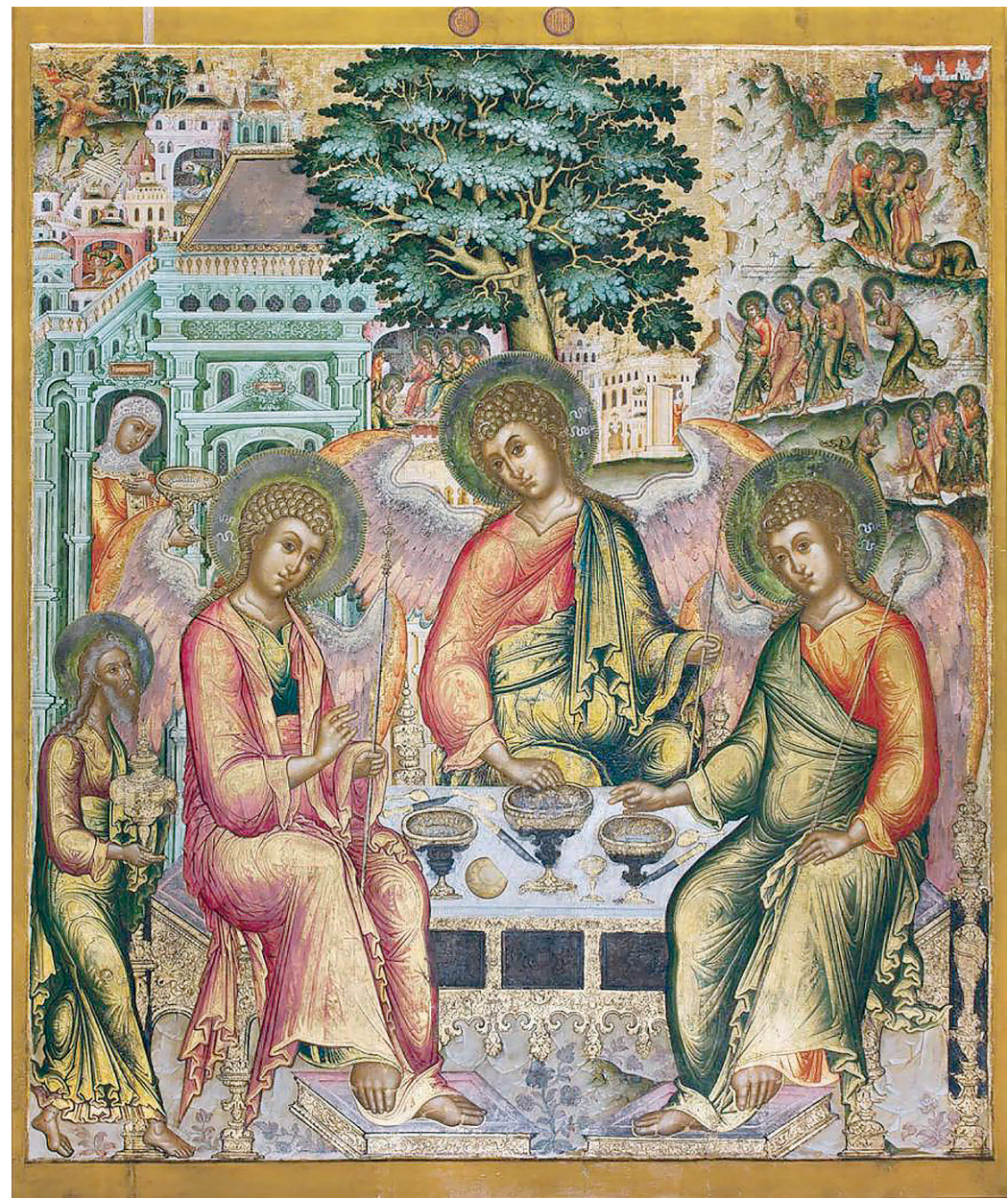

Puc. 1. Святая Троица со сценами Бытия. Икона конца 50-х гг. XVII в. из Троицкого собора Троице-Гледенского монастыря

нописи [3, с. 8-13, 44, 45]. Ранее этот автор писал о «большой храмовой иконе <..> из собора Троице-Гледенского монастыря» как о произведении 1670-х годов, отмечая «высокий уровень профессионального мастерства художника, глубокое и органичное восприятие им передовых по тому времени художественных идей барокко» [4, с.15]. В аннотации из каталога выставки, прошедшей в конце 2013 - начале

2 ВУМЗ. Инв. № 22402. 175,8×147,3×4,2. Доска из 4-х частей, две врезные сквозные встречные шпонки, ковчег; паволока, левкас, темпера. Реставратор С. П. Белов (ВФ МежСНРПМ, 8 мая 1979 1 марта 1983). 
2014 г. в Музее им. Андрея Рублева, произведение отнесено к последней четверти XVII в., а факт его создания в Великом Устюге подвергнут сомнению [5, с. 170-171]. Наконец, в публикации 2014 г. оно воспроизведено с датировкой второй половиной XVII ст. Здесь И.Д. Соловьева и Н. В. Мальцев отмечали, что «его иконография находит близкую аналогию в храмовых иконах середины - второй половины XVII в., в частности иконы 1671 г., созданной Симоном Ушаковым <...> церкви Троицы “В Никитниках" в Москве <..> церкви апостолов Петра и Павла в Устюжне» $[6, \text { c. } 13, \text { кат. } 14]^{3}$. Противоречивость в оценках стиля иконы, подразумевающая диапазон датировок в границах всей второй половины XVII ст. и вариативность во мнениях о принадлежности написавшего ее мастера к той или иной традиции, служат для историка искусства приглашением к детальному анализу художественных черт произведения. Представляется, что образ из Троице-Гледенского монастыря заслуживает того, чтобы стать предметом специального исследования. Первостепенной целью мы ставим перед собой определение его места в художественном процессе XVII в.

Расцвет Троице-Гледенского монастыря, основанного по крайней мере еще в XIII ст. ${ }^{4}$, пришелся на XVII-XVIII вв. На протяжении большей части своей истории он не имел каменных зданий ${ }^{5}$ В 1630 г. здесь стояла «церковь Живоначальные Троицы древена вверх, да теплая церковь Успения Пречистые Богородицы древена клетцки» [10, стб. 924]. Однако в ходе XVII ст. ситуация менялась, и постепенно монастырь превратился в значимый северорусский хозяйственный центр, сравнимый по богатству с крупнейшим монастырем Великого Устюга - Михайло-Архангельским ${ }^{6}$. В 1658 г. старицей Улитой, матерью устюжских купцов Босых, были выделены деньги на перестройку в камне соборного Троицкого храма; в следующем, 1659 г. ростовский митрополит Иона выдал благословенную грамоту на строительство, которое, однако, затянулось так, что в 1693 г. «средь монастыря» находился лишь «начаток здания». В 1697 г. указом патриарха в Троице-Гледенском монастыре было учреждено архимандритское правление, а ныне существующий собор был освящен лишь в 1707 г. $[9, \text { с. 5-8 }]^{7}$.

${ }^{3}$ С. П. Беловым, реставратором иконы «Святая Троица в деяниях», в 2011 г. был сделан доклад на Прокопьевских чтениях в Великом Устюге, оставшийся неопубликованным. По мнению С. П. Белова, «Святая Троица» является работой монаха Сергия, очевидно, 1670-х годов, автора икон «Успение» и «Сошествие Святого Духа» (ВУМЗ), также происходящих из Троице-Гледенского монастыря. Выражаю большую признательность С. П. Белову за эти сведения. К данной гипотезе нам еще предстоит вернуться.

4 Такая дата, а именно вторая половина XIII в., указывается в книге В.П.Шильниковской [7, с. 109]. А. А. Титов называет в качестве даты основания монастыря время около 1190 г. [8, с. 48], О.Б. Зенкова - рубеж XII-XIII вв. [9, с.2].

5 В.П.Шильниковская писала о Великом Устюге как о городе, «вплоть до середины XVII в. не знавшим другого строительного материала, кроме дерева» [7, с.21].

${ }^{6}$ По материалам приходно-расходных книг, содержащихся в фонде № 1187 РГАДА, можно составить представление о хозяйственной жизни обители в XVII в. См.: [11, с.204-228, особ. с. 221]. «На 1678 год за монастырем числилось 60 деревень, полностью или частично, 168 дворов с населением 426 душ мужского пола, работавших на монастырь по договору <...> Основой торговых операций служили хлеб (зерно, мука) и соль» $[9$, с. 3].

7 О причинах длительных сроков строительства см. «Челобитную патриарху Иоакиму игумена Троицкого Гледенского монастыря Андроника на гостя Василия Грудцына в недостройке им в Гледенском монастыре церкви» от 1689-1690 гг. [12, стб. 972]. 
Грандиозный «екатерининский» иконостас Троицкого собора - известное произведение церковного искусства XVIII ст. - создавался в 1776-1784 гг. при участии иконописцев Алексея Колмогорова, Василия Аленова и Егора Шергина [13, с.290-294]. В его композицию кроме новых икон входили и чтимые образы XVII ст., в том числе рассматриваемая «Святая Троица». Следует попутно отметить, что иконам, изображающим Гостеприимство Авраама и Сошествие Святого Духа на апостолов, было отведено особое место в убранстве храма в соответствии с его посвящением. Именно в ходе строительства «екатерининского» иконостаса интересующий нас образ Святой Троицы занял свое нынешнее положение. В «Описи церковного и монастырского имущества Михайло-Архангельского и приписного Троице-Гледенского монастырей» 1842 г. помимо нового образа «Пресвятыя и Живоначальныя Троицы» «по правую сторону царских врат» [14, л. 17 об.] указана и наша, более древняя икона, уже размещенная рядом с «Сошествием Святого Духа» «подле иконостаса на той же стороне в резных золоченых киотах»: икона «Пресвятыя и Живоначальныя Троицы, на ней три вениа с изатами, серебряные, чеканные золочены» (курсив мой. - П.3.) [14, л. 18].

Сведения же о первоначальном расположении «Святой Троицы» можно почерпнуть из других монастырских описей. Опись 1754 г. повествует о двух крупных иконах такой иконографии: «Образ Пресвятыя Троицы писан на красках на нем три венца и три гривны сребряные золоченые чеканные на среднеи гривне привешена панагия, на панагии камени синего образ Вседержителев» на «правой стране» царских врат [15, л. 1 об.] и «Образ Пречистыя и Живоначальныя Троицы писан на красках с твореным золотом» у правого столпа $[15$, л. 4]. По описанию второй из них имел серебряный басменный оклад, следов которого нет на интересующей нас иконе. Следовательно, справа от царских дверей размещалась именно наша «Святая Троица», являвшаяся, как и предполагали ранее исследователи, ключевой частью церковного убранства - храмовым образом.

Икон, происходящих из храмов Троице-Гледенского монастыря, мы знаем совсем немного. Можно лишь догадываться, как выглядели известные по письменным источникам образы «Благовещение», «Лоно Авраамово», «Рождество», «Снятие со Креста» и «Воскресение», от которых в 1517 г. в двадцатый день мая истекло миро [16, с. 92]. Из архивных документов известно, что в 1640-е годы в Гледенском монастыре работали Семен и Иван Гольцовы «с товарищи». Они писали здесь «деисус и праотцы и пророки», реставрировали иконы, Семен Гольцов «поновлял образы над святыми вороты» $[17$, с.91]. В возведенном во второй половине XVII в. каменном соборе до строительства «екатерининского» иконостаса размещался другой иконостас, причем, если верить письменным источникам, не менее внушительный по своим размерам. Он состоял из шести ярусов: местного, праздничного на 16 досках, деисусного, пророческого, праотеческого с «Господом Саваофом» по центру и страстного. В нем находились «глаткие» золоченые царские врата с резными клеймами и «глаткой», покрытой твореным серебром сенью с писанными красками клеймами, изображающими Тайную вечерю, снятие со Креста и положение во гроб [15, л. 1-1 об., 3-3 об. $]^{8}$.

8 В статье В.С.Дедюхиной и Ю.А. Рузавина говорится о том, что в прежнем иконостасе, который в царствование Екатерины Великой было решено заменить из-за ветхости, было 73 иконы $[18$, c. 194]. 
Среди сохранившихся икон, происходящих из Троицкого Гледенского монастыря: «Спас Нерукотворный» ${ }^{9}$, «Успение Богоматери» 1672 г. (рис. 2) ${ }^{10}$ и «Сошествие Святого Духа» 1676 г. ${ }^{11}$ мастера Сергия ${ }^{12}$, «Святитель Николай Чудотворец» и «Одигитрия» 1698 г. работы Стефана Нарыкова (все - ВУМЗ) ${ }^{13}$ - нет близкой стилистической аналогии образу «Святая Троица». В то же время стилистические

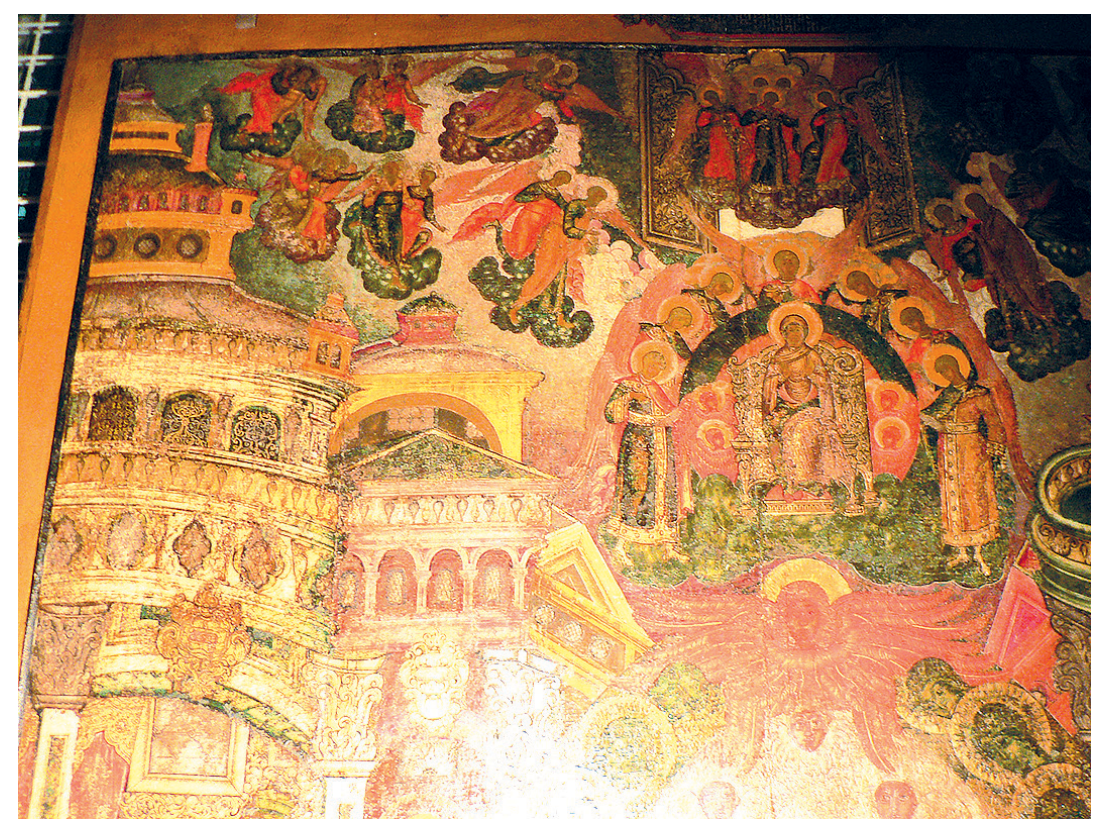

Puc. 2. Успение Богоматери. 1672 г. Фрагмент живописи иконы мастера Сергия

9 ВУМЗ.Инв. № 21632 . $188 \times 153$.

10 ВУМЗ. Инв. № 22428. 175,8×148,5 [19, с. 20, кат. 12].

11 ВУМЗ. Инв. № 22417. 173,5×138, 6×4,2. Доска сосновая, две встречные врезные шпонки, ковчег, левкас, темпера [3, кат. 86, с. 45].

12 О мастере Сергии см.: [20, с.616]. Подписная икона «Успение Богоматери» не упомянута составителями каталога среди известных работ этого иконописца. Ввиду существования гипотезы о принадлежности гледенской «Святой Троицы» его кисти нам бы хотелось обратить внимание на некоторые особенности живописи его подписных произведений, на наш взгляд, противоречащие данному мнению.

Гледенское «Успение» 1672 г. - безусловно, одна из самых больших и самых пышных по стилю икон XVII в., написанных на этот сюжет. Она запоминается своим пламенным, буквально раскаленным колоритом. Темно-зеленый, зеленый насыщенного малахитового оттенка, кажется, использованы лишь для того, чтобы ярче горели превалирующие оранжевые, красные, несколько оттенков розовых, обильно дополненные серебром и золотом. Стиль иконописца Сергия лишен изящества и легкости, колористической рафинированности. Он не стремится к любованию пространственными цезурами, чистыми красками, лаконичными формами. Напротив, Сергий нагружает каждую частичку живописной поверхности иконы орнаментом, или золотыми пробелами, или же облачным узором. Очевидно, авторская манера мастера была стабильной на протяжении долгого времени. Во всяком случае, в стиле созданной им в 1676 г. иконы «Сошествие Святого Духа на апостолов» мы найдем уже узнаваемые художественные приметы: богатые цветовые вариации на тему «огненного» в сочетании с зеленым, золото и серебро, графическую сетку из орнаментов, штрихов, наложенную поверх всей живописи.

13 О мастере и его работах с библиографией см.: [20, с. 435-437]. 
особенности свидетельствуют о возникновении этой иконы задолго до освящения храма (1707 г.). На настоящий момент нам не удалось обнаружить архивных документов, которые могли бы пролить свет на историю создания этого необычного произведения, поэтому при его атрибуции мы опирались на сведения, полученные в ходе стилистического анализа. Прежде чем перейти к их изложению, мы ненадолго остановимся на рассмотрении некоторых черт его иконографии.

До нашего времени дошла большая группа икон Святой Троицы, на которых, как и в интересующем нас произведении, цикл иллюстраций эпизодов из Книги Бытия размещается не в клеймах вокруг средника, а на дальнем плане основной композиции ${ }^{14}$. Самым ранним из них является, по всей видимости, образ конца XVI в., происходящий из Ипатьевского монастыря (ЦИАМ Костромской епархии РПЦ) [5, кат. 75; 23, с. 71]. Данный тип получил широкое распространение в XVII ст. Дополнительные сцены обыкновенно располагались в верхней части средника. Это правило соблюдено в композиции таких икон, как «Святая Троица» 1659 г. из церкви Троицы в Никитниках (рис. 3), времени около 1675 г. из церкви Михаила и Феодора Черниговских чудотворцев в Черниговском переулке в Москве (ГТГ) [5, кат. 76], второй половины XVII в. из церкви Усекновения главы Иоанна Предтечи в Ростове (ГМЗРК) [23, с. 342-343], конца XVII в. из коллекции К. В. Воронина, последней трети XVII в. из Музея им. Андрея Рублева [5, кат. 77, 79], второй половины XVII в. из церкви Покрова села Шунга (ЦИАМ Костромской епархии РПЦ) [24, ил. 156, кат. 99], 1690 г. кисти Кирилла Уланова из Устюженского краеведческого музея ${ }^{15}$. Реже, как это можно видеть на примере образов второй половины XVII ст. из церкви святителя Николая села Дмитриево (ЧерМО) [27, кат. 69. ил. 70] и последней четверти XVII в. неизвестного происхождения из Ярославского художественного музея [28, с. 152-155], иконописцы изображали дополнительные сцены не вверху, а вокруг трех ангелов, и тогда, несмотря на отсутствие клейм, общая композиция напоминала структуру иконы с клеймами. «Святая Троица» из Троице-Гледенского монастыря принадлежит первой, более многочисленной группе икон с «Хождением» в среднике, и в то же время она очень выделяется даже среди этих наиболее близких ей по иконографии произведений.

В правой части ее композиции не представлена праведная Сарра, изображенная на всех перечисленных выше иконах в пандан к образу Авраама. Благодаря этому нюансу из художественной структуры произведения ушло статичное равновесие двух половин, из нее исчез «равнобедренный треугольник», в который в прочих случаях вписывались пять фигур первого плана. Это позволило мастеру укрупнить образы главных «героев»: таких больших (относительно общего формата) ангелов мы не увидим ни на одной из «усложненных» «Ветхозаветных Троиц». Но сугубое внимание зрителя сосредоточивается на крылатых странниках не только из-за масштаба их изображений. Здесь мы имеем дело с редким феноменом: все три ангела смотрят на предстоящего.

14 Считается, что первая икона «Святая Троица в деяниях» была исполнена после пожара 1547 г. для Благовещенского собора Московского Кремля иконописцами из Новгорода. На этой иконе цикл деяний был проиллюстрирован в клеймах. См.: [21, с. 126-137; 22, с. 30, 34]. Следует различать иконографию «Святая Троица со сценами Бытия» и «Святая Троица в деяниях».

15 Воспроизведение: [25, ил. 223]. Этой иконе посвящена специальная работа. См.: [26]. 


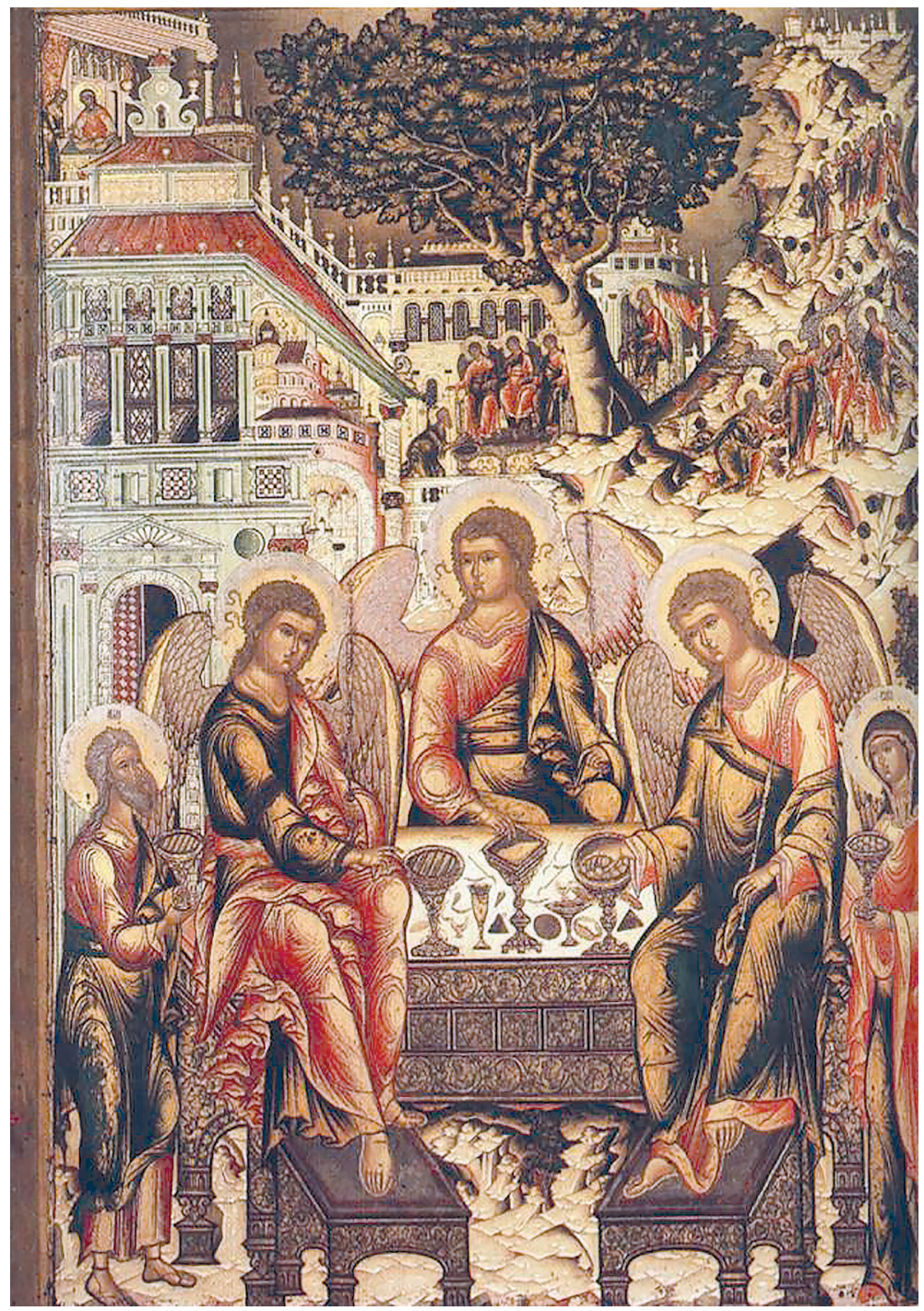

Puc. 3. Святая Троица. 1659 г. Икона из церкви Святой Троицы в Никитниках

На древнерусских иконах Святой Троицы, в краткой или пространной иконографической редакции, небесные вестники обычно вовсе не бросают взгляда на зрителя, или на него взирает только средний из них. Исключение составляют немногие «изокефальные» версии, в которых ангелы демонстрировались сидящими в ряд, фронтально, в одинаковых позах и одеждах и глядящими на нас ${ }^{16}$, и единичные примеры совмещения данного признака с «рублевской» иерархически организованной схемой, притом с гораздо менее выразительной его интерпретацией

${ }^{16}$ См., например, некоторые псковские иконы XVI в.: [29, ил. 41, 144, 145]. 
$\left[5\right.$, Кат. 54, 62, 79] ${ }^{17}$. Мастер иконы из Гледенского монастыря сознательно форсировал сходство трех ликов. Пронзительно ирреальными кажутся три направленных на зрителя одинаковых пристальных взгляда сверкающих очей, напоминающие о том, что Бог с небес смотрит на свое создание ${ }^{18}$, и вызывающие в памяти изречения богословов о Триедином Божестве: «Хотя... и называется многими и различными именами, но Сам Он - Едино. Это же Единое для всякой природы неведомо, невидимо и неизъяснимо» (Преподобный Симеон Новый Богослов) [31, с. 438]. У Святых Отцов можно найти слова о Святой Троице как о Безначальном Боге, «вглядывающемся» в человеческую душу. Тот же святой Симеон Новый Богослов, обращаясь к Нему: «О Отче, Сыне и Душе, Троице Святая, Благо неисчерпаемое, для всех текущее, Красота многолюбезная», - просит Трисиянный Свет «просветить и украсить» его душу, «воззреть» на нее «оком милостивейшим» [31, с. 518-519] (курсив мой. - П.3).

Изображая события, изложенные в XIX и XXII книгах Бытия, мастера, обращавшиеся к теме «Святая Троица», нестрого соблюдали библейскую хронологию. Отчасти это объяснимо тем, что в иконах усложненной иконографии сохранялась композиционная основа краткого иконографического варианта, в котором слева направо располагались шатер (палата, сень), дуб и высокая горка. Закрепленность места действия предопределила несоответствие изображения нарративу (sic!): в левой половине оказались события, совершавшиеся в шатре, а в правой - те, что разыгрывались на лоне природы. На иконах Святой Троицы со сценами Бытия конца XVI - третьей четверти XVII в. противопоставление палаты горке продолжало сохранять важное композиционное значение, в то время как с конца XVII - начала XVIII столетия наблюдается процесс разрушения структуры, когда либо палаты «расползались» вправо [5, кат. 79], либо горки занимали всю верхнюю часть изображения [24, кат. 292, 293].

Итак, на иконах Святой Троицы рассматриваемого типа иллюстрировались сразу несколько эпизодов из Книги Бытия. Наиболее «ранний», соответствующий словам Священного Писания: «Он [Авраам] возвел очи свои и взглянул, и вот, три мужа стоят против него. Увидев, он побежал навстречу им от входа в шатер (свой) и поклонился до земли» (Быт. XVIII, 2), - обыкновенно демонстрировали в правой верхней четверти композиции, на фоне пейзажа, но не в самом верху, далее, как правило, изображались следующие эпизоды, также посвященные теме встречи небесных вестников: «Авраам, провожающий путников в свой дом» и «Омовение ног ангелам» (Быт. XVIII, 3-5).

17 Среди икон «Ветхозаветная Троица со сценами Бытия» без клейм обращает на себя также внимание прошедший недавно реставрацию образ второй половины XVII в. из собрания ГМО «Художественная культура Русского Севера». См.: [30, с. 114-117]. Икона необычна своей композицией. Рядом с центральной группой ангелов не представлена Сарра, в то время как фигура праотца Авраама показана не сбоку, а слева, между двух небесных вестников. Изображение центральной группы смещено в правый нижний угол композиции, а все три ангела смотрят на зрителя.

Иконографии Святой Троицы в древнерусском искусстве посвящена обширная литература. См. изложение основных вопросов и библиографию в статьях Г.В.Попова, Л.В.Нерсесяна и Н.И. Комашко из упоминавшегося выше издания 2013 г. «Преподобный Сергий Радонежский и образ Святой Троицы в древнерусском искусстве».

18 Пс. XIII, 2. Господь с небес призрел на сынов человеческих, чтобы видеть, есть ли разумеющий, ищущий Бога. 
На нашей иконе эта тема раскрывается в трех сценах. Изображение самой встречи размещается довольно высоко, если сравнивать художественное решение образа с иными иконами на данный сюжет. Три ангела представлены здесь спускающимися с вершин, будто замедлившими свое движение перед коленопреклоненным Авраамом. Их фигуры показаны без пространственных цезур, сближены, а над головами помещена надпись в три строки: «И видех Авраам трех мужей стоящи прямо лица его / И притече и поклонися до земля и рече Господи, аще обретох / благодать пред лицем твоим, не мини раба своего». Ниже этой композиции в чуть большем масштабе три ангела и праотец представлены идущими в дом Авраама. Фигура старца здесь замыкает группу. Судя по надписи над Ангелами (Быт. XVIII, 4-5), провожая путников в шатер, он говорит слова гостеприимства: «Да ся принесет и омыются ноги ваша и прохладитеся / под дубем и принесу хлебы да ясте и посем минете на путь свой / егоже ради совратистеся... рабу своему». На пути Авраама и небесных вестников чуть в отдалении иконописец изобразил палату золотистого цвета, а также Сарру, отворяющую дверь и высматривающую гостей.

Затем действие переносится в левую часть композиции, где в разных комнатах дома Авраама, представленного в виде роскошного дворца, показаны не сопровождающиеся библейскими цитатами «Умовение ног странникам», «Приготовление Саррой хлебов» (Быт. XVIII, 6) и «Заклание отроком тельца» (Быт. XVIII, 7). Следующие эпизоды: трапеза и пророчество о рождении у Авраама и Сарры сына (Быт. XVIII, 8-10) - запечатлены на первом плане ${ }^{19}$. Далее повествование «возвращается» в правую половину, где у подножия горы показан уход небесных странников от Авраама (Быт. XVIII, 16) ${ }^{20}$. Размещение изображения ухода ангелов из дома Авраама у подножия горы неизвестно нам ни по одной другой иконе Святой Троицы в деяния ${ }^{21}$.

Благодаря «переносу» к основанию скал фигур четырех уходящих здесь, на горке, совсем близко, на сравнительно небольшом пространстве, в трех ярусах оказались сразу три похожие мизансцены. Хотя в них мы видим одних и тех же «героев», они не производят впечатления повторяемости действия или монотонности. И в этом - исключительная заслуга художника, сумевшего мастерски разнообразить три, казалось бы, чрезвычайно схожие иконографические ситуации. Буквально чуть-чуть он варьировал их в масштабе, и варьирование это сюрреально: наиболее близкие к нам фигуры представлены в среднем ярусе, поменьше - в верхнем, и довольно неожиданно самые малые - в нижнем. В каждой группе - три разных расположения ангелов. Один из них, облаченный в зеленый хитон и розовый гиматий, сначала возглавляет шествие, затем становится посреди других и, наконец, изображается замыкающим группу. Движения трех групп по-разному направлены и по-разному ритмически организованы, и отличия всякий раз характеризуют конкретную ситуацию (встречу, путь в дом и проводы), позволяют связать каждую сцену с конкретными эпизодами Священного Писания. Три группы воспринимаются

19 Мастер не упустил из виду подробность, о которой упоминает библейский текст. Как и на многих других иконах Ветхозаветной Троицы, Сарра представлена позади Авраама и ангелов, под аркой палаты, слушающей пророчество «у входа в шатер, сзади его» (Быт. XVIII, 10).

20 Фрагмент данного текста Священного Писания воспроизведен на гледенской иконе в надписи в четыре строки над нимбами ангелов.

${ }^{21}$ Как правило, оно размещалось, наоборот, наверху горки. 
в единстве, связанные друг с другом как нерасторжимые части одной художественной ячейки, однако благодаря надписям и нюансам иконографической интерпретации становится понятно: события, проиллюстрированные в двух верхних сценах, не предшествуют непосредственно событию, представленному внизу.

В цикл «деяний» на иконе из Гледенского монастыря включены сцены «Гибель Содома» и «Жертвоприношение Авраама» (рис. 4). Наиболее драматичные из всех, они расположены симметрично в верхних углах. В виде клейм обе композиции можно встретить в древнерусской живописи уже во второй половине XVI ст., например на иконах второй половины XVI в.: из Покровского монастыря в Суздале (до 1587 г.) (ГРМ) [32, с. 55] и из бывшего собрания А. В. Морозова (ГТГ) [5, с. 162163]. Известны также случаи их включения в композицию икон со сценами Бытия на дальнем плане, хотя в подобных произведениях их изображали далеко не всегда.

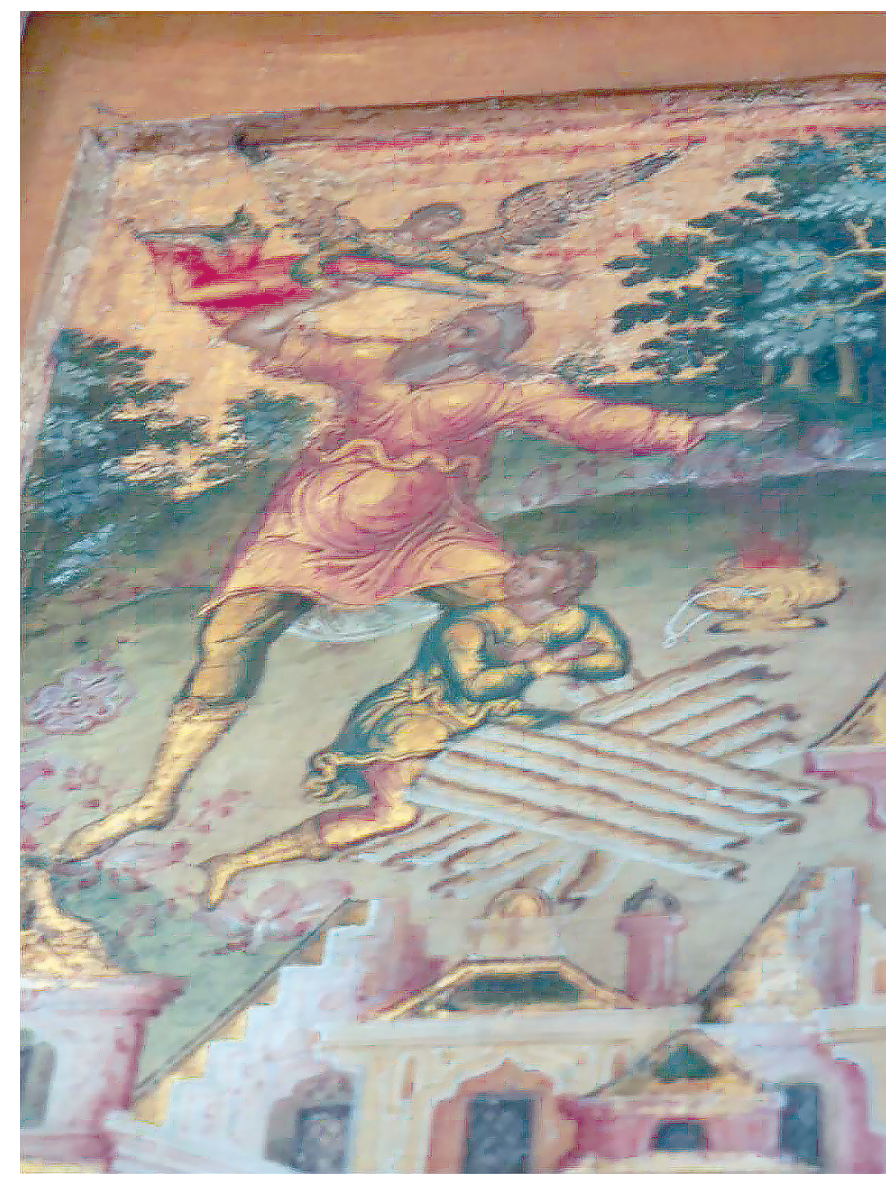

Puc. 4. Жертвоприношение Авраама. Фрагмент живописи иконы «Святая Троица» из Троице-Гледенского монастыря

Их нет на упоминавшихся иконах конца XVI в. из Ипатьевского монастыря, 1659 г. из церкви Троицы в Никитниках, второй половины XVII в. из церкви Покрова села Шунга. На иконе середины XVII ст. из Спасо-Преображенского собора Спасского 
монастыря в Ярославле (ЯХМ) [28, с. 160-163] изображен только один из этих сюжетов - «Жертвоприношение Авраама».

В связи с иконографией образа «Святая Троица» из Троице-Гледенского монастыря отдельное внимание необходимо уделить сценам «Жертвоприношение Авраама» и «Сарра, ожидающая гостей». Особенности их трактовки говорят о прямом или опосредованном знакомстве иконописца с западноевропейскими иллюстрированными изданиями, а именно с ветхозаветным циклом Библии Пискатора ${ }^{22}$. Посвоему интерпретировав образец, мастер сохранил его композиционную основу. В изображении жертвоприношения Авраама переданы характерные взаиморасположения фигур Исаака, Авраама и ангела, специфические движения этих героев, даже детали (дымящийся котелок и сложенные дрова), которые можно увидеть на одноименной гравюре из Библии Пискатора (рис. 4, 5). Сложнее обстоит дело со

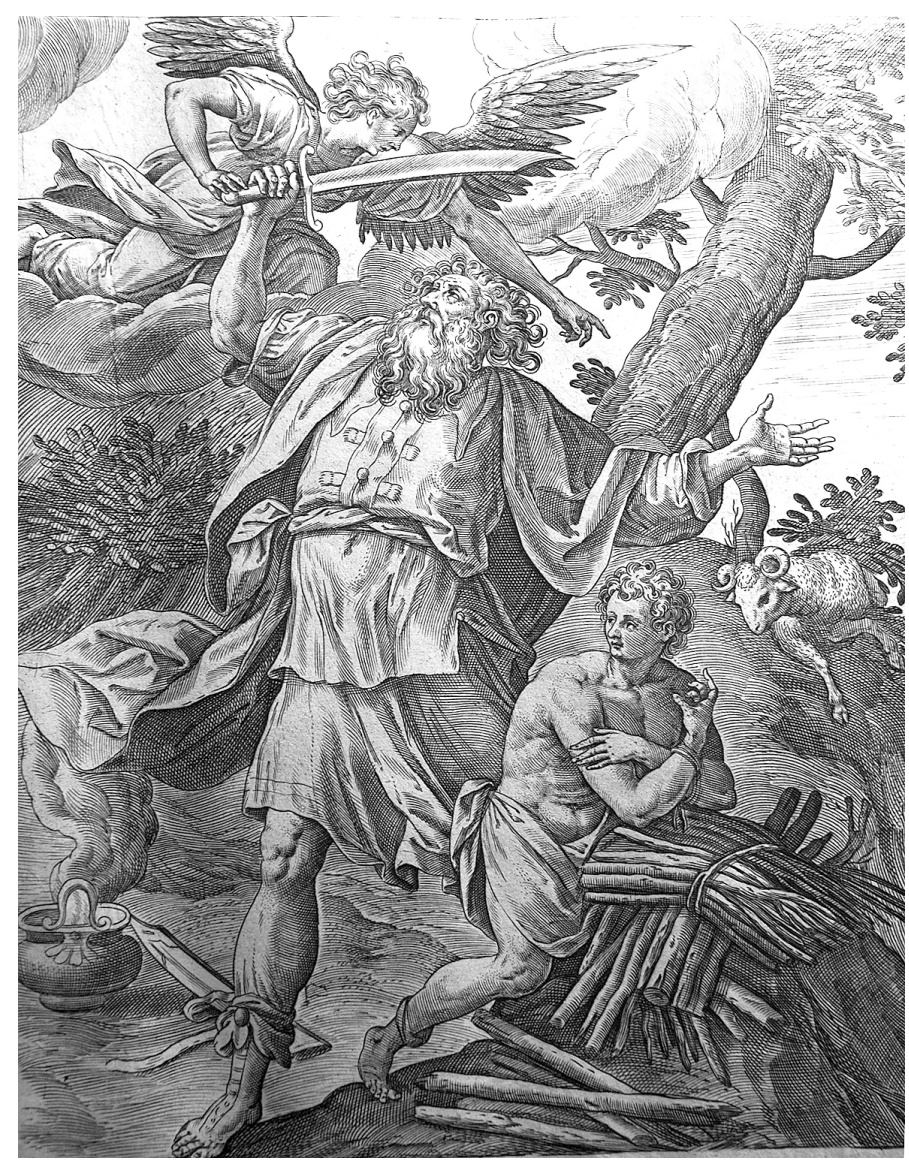

Puc. 5. Жертвоприношение Авраама. Фрагмент гравюры Библии Пискатора 1646 г.

22 С этим циклом мы ознакомились в издании Библии Пискатора 1646 г. из собрания Русского музея (ГРМ, инв. ДР / Гр. 80). Выражаю свою признательность хранителю, старшему научному сотруднику отдела древнерусского искусства М. В. Федосеевой за возможность осмотреть интересующие нас гравюры - «Гостеприимство Авраама» и «Жертвоприношение Авраама». 
второй композицией - «Сарра в ожидании гостей», поскольку ее иконографический прототип несет в себе совсем другой смысл. Создавая этот поразительный по красоте фрагмент живописи (здесь особенно важен перепад масштабов, соприсутствие высокой вздымающейся горы, огромного цветка и крошечной фигурки, рис. 6), изограф обратился к гравюре «Гостеприимство Авраама», использовав из нее только сцену дальнего плана (рис. 7). На этой гравюре Сарра представлена в проеме врат, прислонившейся к дверному косяку. Хорошо узнается общая иконографическая ситуация, тем более примечательно, что на иконе она наделена другим смыслом. В Библии Пискатора это не Сарра, ожидающая гостей, но Сарра, слушающая пророчество странников о том, что она родит сына.

Несмотря на обилие деталей, наличие которых было предписано выбором композиционной схемы, мастер гледенской «Троицы» сохранил четкую иерархию в расстановке акцентов. Сосредоточению внимания на ликах ангелов способствует особенный прием: иконописец отказался от золота в изображении нимбов и «перенес» его в их сердцевину, представив небесных вестников златовласы-

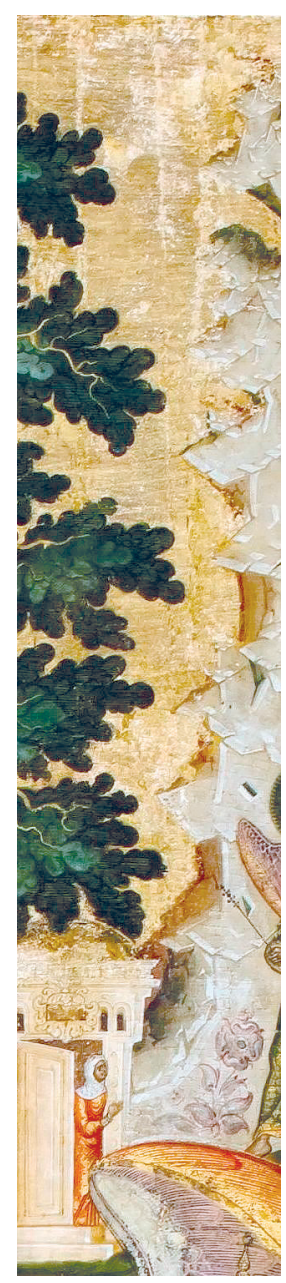

Puc. 6. Праведная Сарра, ожидающая гостей. Фрагмент живописи иконы «Святая Троица»

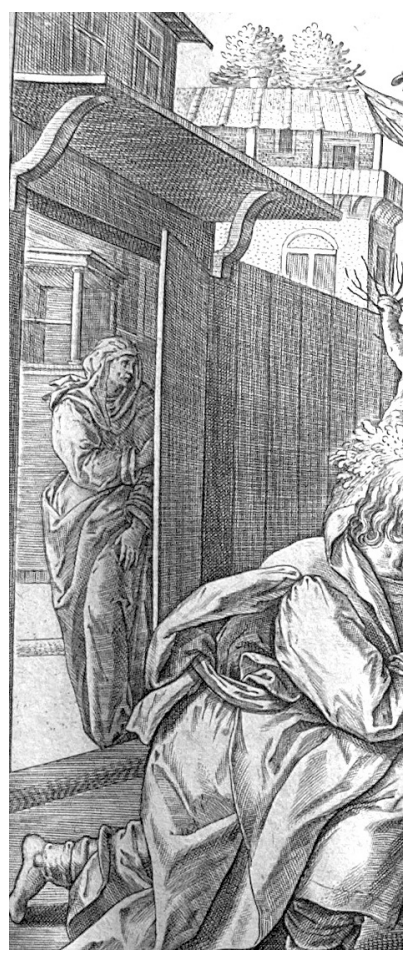

Рuc. 7. Святая Сарра, слушающая пророчество. Фрагмент гравюры «Гостеприимство Авраама» из Библии Пискатора 1646 г. 
ми ${ }^{23}$. Необыкновенно красивы их прически, уложенные рядами изящных завитков и спадающие двумя вьющимися прядями вдоль шеи. Контуры золотого вихра надо лбом вторят острым очертаниям ворота одежд. Золотые нити, искусно вплетенные в волосы, придают странникам сказочно-фантастический облик. Очень специфичен физиогномический тип их ликов.

Сила воздействия произведения во многом обусловлена сочетанием в его живописи противоположных качеств: масштабность и величественность сопряжены в ней с ювелирной работой кисти. По нему можно судить о наивысших достижениях русского искусства XVII ст. Выполненная как храмовый образ, предназначенный для размещения у самих царских врат, икона была написана с особым тщанием. Крупная по размеру, она светится от обилия золота, служащего в качестве фона, покрывающего крыши палат, ствол и ветви дуба, одежды, предметы мебели, сосуды на столе. Фигурирует оно и в виде описи ступней ангелов, а также ассиста их крыл и волос. Просветленно-торжественный колорит иконы построен на множестве тонких цветовых сочетаний. Золотистые прозрачные охры соседствуют с голубовато-зелеными «морозными» оттенками, серо-жемчужные с холодными и теплыми светло-зелеными. Единственное крупное темное пятно в композиции, находящееся в самом ее верху по центру, - изумрудная листва Мамврийского дуба - лишь подчеркивает общую светлость палитры.

Живопись произведения находит множество точек соприкосновения с памятниками ведущего стилистического течения середины XVII в., представленного в первую очередь работами царских мастеров. Наивысшего расцвета данный стиль достиг в конце 40-х и в 50-х годах XVII ст., однако его отголоски в той или иной мере чувствуются в искусстве всей второй половины XVII в. Образ из Троице-Гледенского монастыря не предстательствует за вторичное искусство, а является плодом стиля на гребне его развития. Автор «Святой Троицы», несомненно, связанный с устюжской художественной культурой, очевидно, трудился в середине XVII в. и привлекался к иконописным работам в столице ${ }^{24}$. То искусство, которым он владел, имеет широкую стилевую природу, не укладывающуюся в категории авторской манеры. Стиль, к которому оно принадлежит, был незаслуженно забыт историками культуры, поскольку соседствовал во времени с ярчайшим явлением - «живоподобным» искусством Симона Ушакова, а точнее, предварял его. Примечательно, что при разговоре о русской живописи 1640-1650-х годов в большей степени разговор ведется о фресках ${ }^{25}$. И в этом состоит еще одна причина ускользания от внимания иссле-

${ }^{23}$ Приведем некоторые другие примеры подобной трактовки прядей волос в искусстве XVII ст. Это изображения причесок на иконах «Эммануил с ангелами» 1650 г. из церкви Пророка Ильи в Ярославле (in situ) и «Деисус с Эммануилом» из коллекции П. Д. Корина 70-х гг. XVII в. (ГТГ).

${ }^{24}$ Как известно, в середине - второй половине XVII ст., в период экономического и культурного расцвета города, устюжских иконописцев высоко ценили в Москве. См., например: «О существовании в Устюге школы иконописи может свидетельствовать большое число живописцев, работавших в городе в XVII веке. Только за период 1660-1670 годов известно более двадцати пяти художников-устюжан, которые вызывались в Москву и Оружейную палату на живописные работы <...> Из документов XVII века следует, что Устюг по числу живописцев, присылаемых в Москву, иногда состоял на третьем месте после Новгорода и Ярославля» [33, с. 140]. Об иконописи Великого Устюга в XVII в. см. также: [16, с. 70-76; 7, с. 206-208].

25 Так в общих трудах о русском искусстве XVII в. [34; 35, с. 345-466]. Следует отметить здесь некоторые другие работы, в которых дискутируются проблемы изобразительного искусства 1650-х годов. См.: [36, с. 59-74; 37, с. 13-64]. 
дователей факта существования «роскошного» стиля, который был связан именно с иконой. Интуитивно его бытие провидели И.Е.Данилова и Н.Е. Мнева, давшие точную характеристику его свойствам, описывая одно произведение - «Благовещение с Акафистом» 1659 г. из московской церкви Святой Троицы в Никитниках. Описание заканчивается словами, с которых уместно начать наши рассуждения: «Икона... свидетельствует о том, что в конце 50-х гг. в живописи Москвы существовали различные направления, среди которых ушаковскому направлению не принадлежало первенства» $[35, \text { с. 374 }]^{26}$. Среди множества стилистических направлений этого времени первенство принадлежало именно тому, за которое предстательствует живопись никитниковского «Благовещения». Речь идет о придворном стиле первых пятнадцати лет царствования Алексея Михайловича Романова.

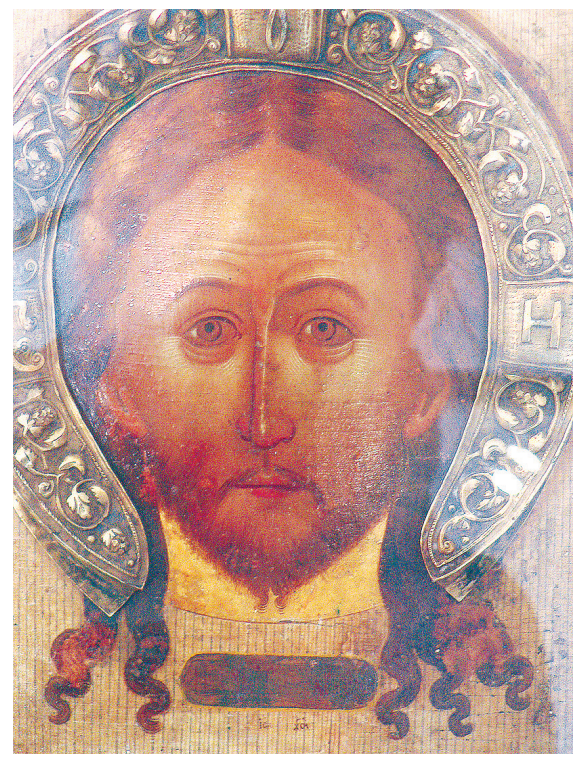

Puc. 8. Спас Нерукотворный. Икона середины XVII в.

Одни и те же качества художественной формы объединяют такие произведения, как «Святые Алексий человек Божий и Мария Египетская» 1648 г. кисти Якова Рудакова Казанца (ММК) [38, кат. 58, с. 146-147], «Явление Богоматери преподобному Иосифу Волоцкому» (ГРМ) [39, кат. 166, ил. на с. 135], мерная икона «Святая София» 1657 г. (Музей «Новодевичий монастырь») [40, кат. 225, c. 404], образы «Благовещение» и «Святая Троица» 1659 г. из иконостаса церкви Троицы в Никитниках (рис. 3), из его деисусного и праздничного рядов, икона «Богоматерь “Благодатное небо"» 1640-х годов из южного придела этого же храма ${ }^{27}$, «Спас Эммануил» второй четверти XVII в. из Троицкой церкви села Уницы Тверской области (МиАР) ${ }^{28}$, «Спас Смоленский» 1651 г. работы Василия Федорова Тарарина (МиАР) ${ }^{29}$, иконы Федора Зубова 1660-1661 гг. из церкви Ильи Пророка в Ярославле (ЯМЗ), о которых речь пойдет

ниже. К этому же стилю, на наш взгляд, принадлежат также такие произведения, как «Рама с чудесами Богоматери Казанской» из деревни Нюба (Сольвычегодский музей) $[42, \text { кат. 63, с. 69-70, 187] }]^{30}$, «Спас Нерукотворный» (ВУМ3) (рис. 8) ${ }^{31}$, икона

26 Здесь нам бы хотелось привести некоторые точные слова, подобранные авторами для описания иконы «Благовещение»: «Живопись клейм, с их тонким миниатюрным письмом, мелкими изящными, почти хрупкими фигурками, разбросанными среди детально разработанного пейзажа и архитектуры, имеет мало общего с манерой Ушакова. Краски не такие чистые и звонкие, как в иконах предшествующих столетий, но переливчатые, с оттенком розового, оливково-зеленого, бледносиреневого и голубого в сочетании с позолотой. Гамма эта весьма нарядная, но холодная» [35, с. 374].

27 См. воспроизведение: [34, ил. 18, 19; 41, с. 134-139, 143-145, 148-153, ил. 152, 160, 170, 176$].$

28 Осмотрена на экспозиции музея.

29 МиАР. Инв. № КП 1939. $31,8 \times 22,5$ [21, с. 646].

30 В каталоге живопись рамы опубликована с датой «XVII в.», мы поддерживаем другой вариант ее датировки, указанный в статье Н. Н. Чугреевой [43, с. 96], - вторая четверть XVII в.

31 Осмотрена на экспозиции музея. 
«Святой Алексий, Человек Божий» (ГИМ), датируемая на данный момент первой половиной XVII в. ${ }^{32}$

Хронологические границы, географию распространения и этапы эволюции стиля еще предстоит уточнять, на настоящем этапе для нас важны его общие свойства. Итак, для «роскошного» стиля характерны смелые совмещения пастельных и ярких цветов, фантастические рафинированные архитектурные и пейзажные фоны, обилие золота, графичность, доводимая порою до сухости, при некоторой грузности форм. В этом стиле, предшествовавшем возникновению новой художественной системы, создателем которой считают Симона Ушакова, зародились отдельные приметы живоподобия, в частности интерес к белильным плавям в личном письме. В целом же «ушаковский» стиль развивался как антитеза «роскошному», под знаком простоты в противовес преизбыточности искусства царских мастеров предшествующей фазы его развития.

Рассматриваемое стилистическое течение имело истоком иконопись Москвы первой четверти XVII в. Оно связано с таким сложным явлением, как «строгановская» икона, причем тяга к узорочью, декоративности, свойственная лучшим строгановским мастерам, достигла своего апогея именно в середине столетия. Общая стилевая структура иконы «Ветхозаветная Троица» из Троице-Гледенского монастыря вызывает ассоциации в первую очередь с произведениями «роскошного» стиля середины XVII в. Она близка им спецификой колорита, особенностями использования узорочья, трактовкой пространства. Чтобы в этом убедиться, достаточно сравнить ее с иконами «Благовещение» и «Троица в деяниях» из церкви Святой Троицы в Никитниках. Все три образа производят ошеломляющее впечатление. Взгляду трудно сфокусироваться из-за обилия деталей, ракурсов и планов. Элементы обратной и прямой перспективы смешаны, формы из-за своего обилия едва умещаются в пространстве, превалируя над ним.

Мы предлагаем, однако, еще более конкретизировать атрибуцию произведения, определив его как памятник круга (?) Федора Зубова ${ }^{33}$, созданный в конце 1650-х - самом начале 1660-х годов. Такой вывод позволяет сделать его необычайная близость датированным образам местного ряда церкви Ильи Пророка в Ярославле, написанным этим прославленным иконописцем в кратчайшие сроки, вероятно, при участии нескольких помощников.

К началу 60-х гг. XVII в. Федор Зубов заслужил признание в своих родных северных землях, в Великом Устюге и Сольвычегодске, где он работал и жил, в Мос-кве и Ярославле. Это время - рубеж, которым заканчивается ранний и наиболее яркий период его творчества. В числе созданных им на данном этапе икон «Спас Нерукотворный» 1654 г. (СИХМ) [20, с.257] и «Святой Иоанн Предтеча» середины XVII ст. (ГМЗРК) (рис. 9) [23, с.264-265]. По мнению В.Г.Брюсовой, его кисти принадлежат также иконы середины XVII в. «Святитель Николай Чудотворец» (ВУМЗ) и «Иоанн Предтеча - Ангел пустыни» (ГТГ) [47, с. 33-34; 48, c. 260-261, ил. на с. 262]. Иоанникий Скрипин, которому требовался изограф для восстановления иконописного ансамбля в Ильинском храме после пожара 1658 г., разыскал Федора Зубова в Сольвычегодске, откуда перевез его с детьми и женой

$32146 \times 101$ [44, кат. 478, ил. 174].

33 Литература, посвященная творчеству этого мастера, обширна. См.: [20, с. 250-259] (с основной библиографией). Литература, не указанная в Словаре: [45, кат. 4, с. 28-31; 46, с. 135-138, 150-151]. 


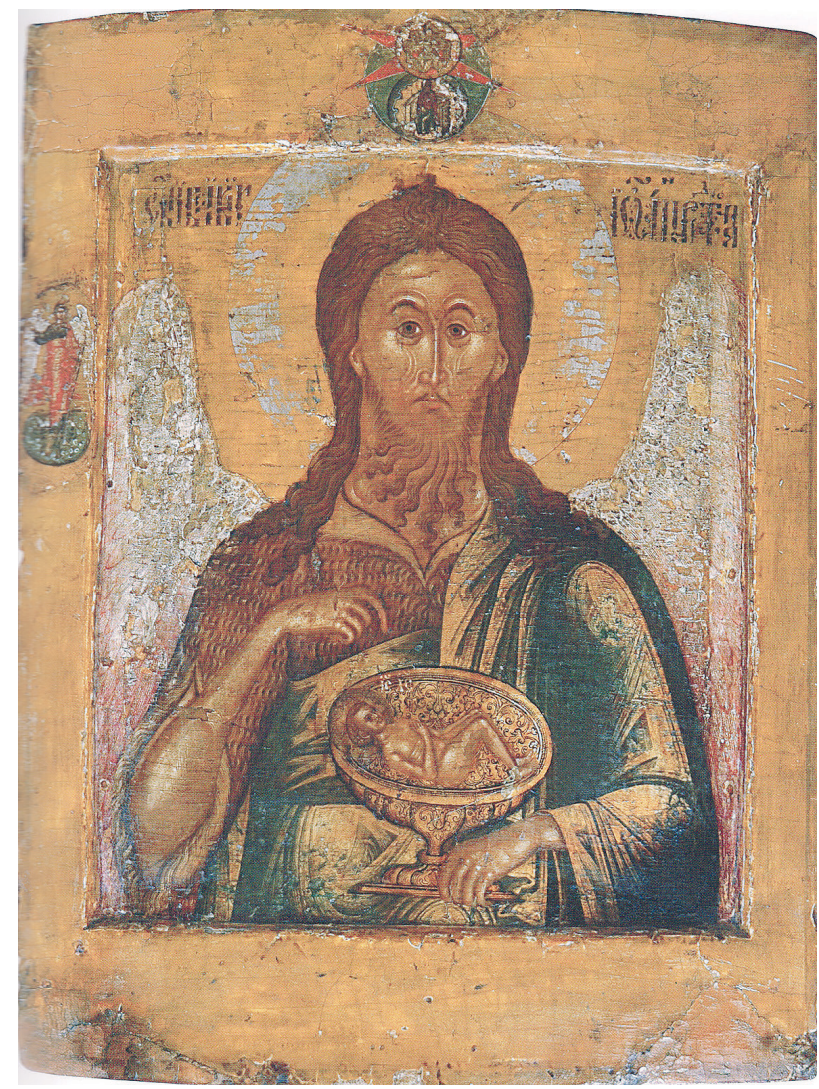

Рuc. 9. Иоанн Предтеча - Ангел пустыни. Федор Зубов. Середина XVII в.

в Ярославль. В 1660-1662 гг. он создал наиболее важные для понимания всего его творчества произведения - иконы ярославской Ильинско-Покровской церкви (эти сроки пребывания мастера в Ярославле были определены Т.Е. Казакевич) ${ }^{34}$. Ансамбль сохранился до нашего времени, в него входят большого размера иконы «Илья Пророк в пустыне», «Покров Богоматери», «Иоанн Предтеча - Ангел пустыни», «Вознесение Господне», «Благовещение Пресвятой Богородицы», «Апостольская проповедь», «Богоматерь Владимирская», «Святители в предстоянии Богоматери Знамение» и клейма рамы с «Акафистом Богоматери» вокруг иконы «Богоматерь Тихвинская». По завершении этих работ он уехал в Москву и в 1662 г. был зачислен в штат Оружейной палаты [49, с. 120].

Исследователями неоднократно отмечалась глубокая оригинальность стиля «ильинских» икон начала 60-х годов XVII в. На всех них, даже тех, которые предположительно писались при участии помощников мастера ${ }^{35}$, лежит печать автор-

34 Об иконах Федора Зубова из церкви Пророка Ильи см.: [47, с. 43-79; 37, с. 39 и далее].

35 Определение в этом ансамбле икон, которые писались Федором Зубовым самостоятельно, совместно с мастерской или даже только его помощниками, - предмет отдельной научной дискуссии. Представление об этой полемике можно составить, сопоставляя мнения разных ученых [37, c. 42,$57 ; 47$, c. $44-46 ; 36$, c. 104$]$. 
ского ви́дения. Данные произведения, безусловно, связаны с описанным выше «роскошным» стилем 1640-1650-х годов. В них мы находим и высокую степень наполненности изобразительного поля узорочьем, и избыточность форм по отношению к отведенному им пространству, и светлость палитры. Однако в их художественном мире есть также нечто существенное, не укладывающееся в категории стиля эпохи. В стиле упоминавшихся выше икон «Святой Алексий человек и святая Мария Египетская» 1648 г., «Спас Смоленский» 1651 г., «Богоматерь Благодатное небо» 1640-х годов, «Троица Ветхозаветная» 1659 г. превалирует линейная составляющая: акцент поставлен на выразительности изящных контуров, ломких, подчас хрупких абрисов фигур и предметов. Для Федора Зубова важнее движение масс, и в этом качестве его искусство родственно скульптуре. Складки одежд, облачающих его героев, исполнены пластичности и тектоники. Его образы пронизаны таким пафосом и мощью, которых мы не найдем в каких-либо других произведениях 1640-х - начала 1660-х годов. Очевидно, что это произведения переходного стиля.

Вне непосредственного анализа, уже при чтении литературы об иконах местного ряда церкви Ильи Пророка можно обнаружить некоторые характеристики, в равной степени приложимые к гледенской «Троице»: «"Позднестрогановские традиции” Зубова, метко подмеченные И.Э.Грабарем, своеобразно сочетались в его творчестве с приемами светотеневого “живописания” ушаковской школы, с которыми молодой восприимчивый иконописец познакомился в Москве» [37, с.45]. Стилистическое сходство «Святой Троицы» из соборного храма Гледенского монастыря с группой икон, исполненных Федором Зубовым и его товарищами для Ильинской ярославской церкви ${ }^{36}$, имеет такой характер, что позволяет говорить о создании рассматриваемого образа едва ли не самим Федором Зубовым, по крайней мере с уверенностью писать о принадлежности гледенской «Троицы» и ярославского ансамбля одной и той же художественной традиции.

Не вдаваясь в аналитические подробности, отметим общие непосредственно воспринимаемые черты сходства этих произведений. Это и тяготеющий к квадратному формат иконных досок (ср. с иконами «Иоанн Предтеча - Ангел пустыни» и «Илья Пророк со сценами жития»), глубина их ковчега и окраска полей едва ли не одним колером насыщенного теплого охристого цвета, сочетание в одеждах некоторых персонажей характерного оттенка зеленого и красного цветов, почти сплошь покрытых золотом, рисунок которого производит совершенно особенный графический эффект (ср. одежды центрального ангела с одеждами Христа с иконы «Апостольская проповедь»), пропорциональный строй, трактовка пространства, отношение к узорочью (с использованием одних и тех же мотивов) etc.

Выше мы уже писали о личном письме гледенской «Троицы» применительно к особому ракурсу ликов трех небесных вестников. Однако специфика техники исполнения и стилизованных анатомических примет в изображении ликов, кистей рук и ступней ног простирается гораздо шире. При ближайшем рассмотрении ошибочной оказывается самая первая ассоциация, возникающая при созерцании ильинского ансамбля и гледенского шедевра. Речь идет о «живоподобии» лично-

36 Манера письма ильинских икон 1660-1662 гг. сравнительно с манерой исполнения образа «Святая Троица» более свободная, широкая. Это объясняется тем, что иконы для ярославского храма мастеру было необходимо создать в предельно сжатые сроки. 
го письма этих произведений ${ }^{37}$. Среди приметных черт их стиля - мощь пластики, «скульптурная» материальная весомость представленных на них персонажей. В этой выявленности «телесного», безусловно, есть определенное созвучие живоподобным образам. И все же трактовка изображения плоти на иконах Оружейной палаты в варианте Симона Ушакова 1660-1670-х годов и на гледенском и ильинских образах существенно различается. Разница проступает в том числе в физиогномических особенностях (рис. 10, 11, 8).

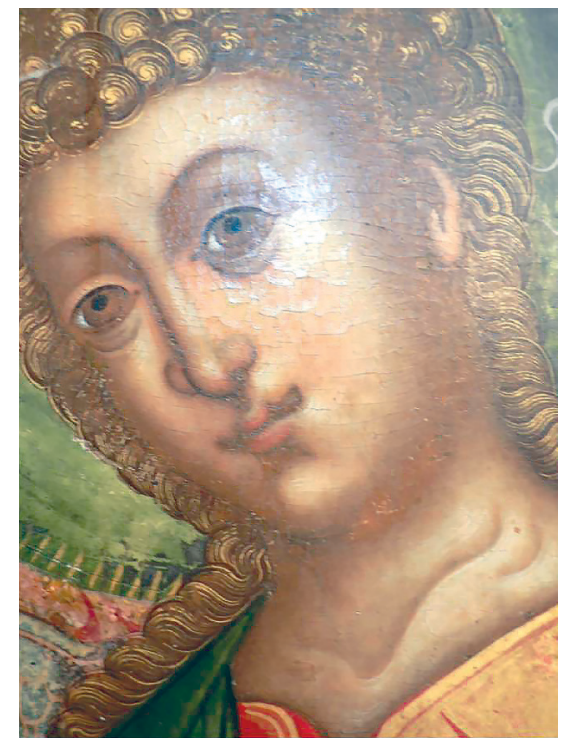

Рuc. 10. Ангел. Фрагмент живописи иконы «Святая Троица»

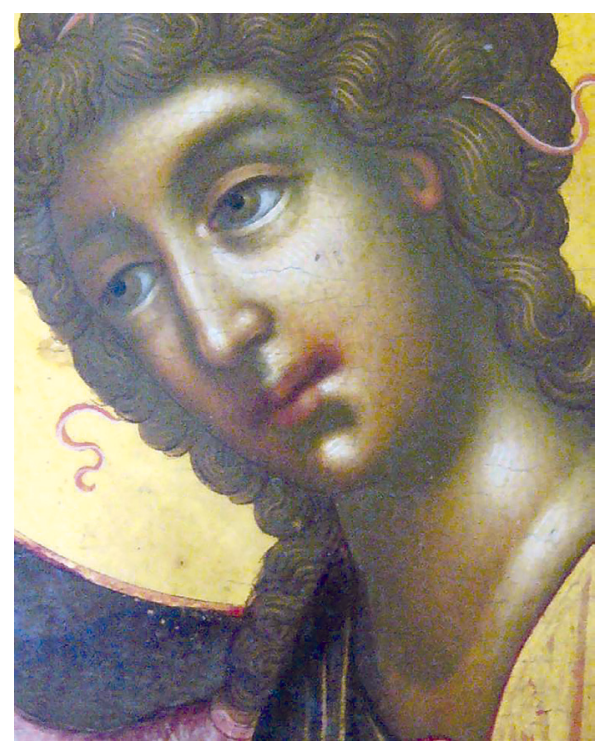

Рuc. 11. Ангел. Фрагмент живописи иконы «Святая Троица» Симона Ушакова 1671 г. ГРМ

Здесь не найти таких «ушаковских» примет, как подчеркнутая плавность в абрисе овала лица, а в изображении глаз - намеченной толщины нижнего века. Зато мы обнаруживаем отсутствующие в «живоподобной» системе разгранку на две части глазной впадины, широко распахнутые глаза с оттянутыми стрелкой «внешними» краями и некоторые другие восходящие еще к «строгановской» иконе начала XVII в. черты, например жирную обводку нижнего контура верхнего века. C точки зрения логики организации черт личного письма иконы Федора Зубова из церкви пророка Ильи и гледенская «Троица» находят аналогии в некоторых других произведениях середины XVII в., принадлежащих «роскошному» стилю, например в образах «Спас Нерукотворный» (ВУМЗ) и «Спас Эммануил» (МиАР).

Богатый художественный мир иконы «Святая Троица» населен множеством героев. Кроме крупных образов ангелов здесь присутствуют среднего размера изображения святых Авраама и Сарры и на дальнем плане - несколько миниатюрных фигурок. Весьма выразителен образ праведного Авраама (рис. 12). Его

37 Об этом явлении с библиографией см. статьи из каталога выставки произведений Симона Ушакова, прошедшей недавно в Третьяковской галерее: [50; 51; 52]. 
рафинированная утонченность достигнута за счет удлиненности пропорций: высокой шеи, протяженных прядей седых волос, плавных, немного манерных черт лица. Показательно его сравнение с фигурой пророка Ильи на иконе «Пророк Илия в житии» из Ильинского ярославского храма (рис. 13). Нутровую близость двух ликов трудно исчислить списком признаков сходства. В обоих случаях взгляд привлекают напряженный «дальний» контур лика со «вдавленной» по отношению ко лбу и бороде скулой и выпуклой «линзой» верхнего века; одного типа рисунок

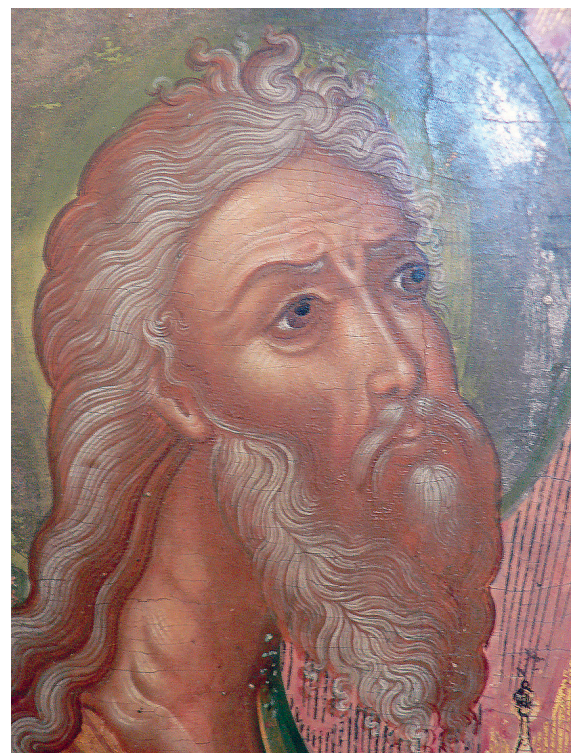

Puc. 12. Праведный Авраам. Фрагмент живописи иконы «Святая Троица»

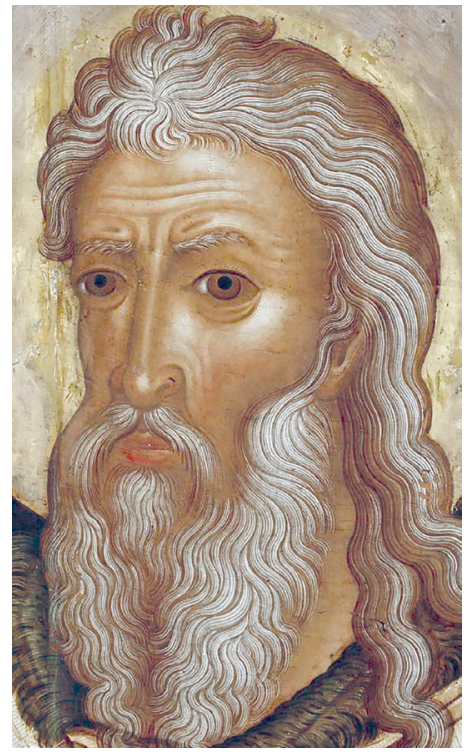

Рuc. 13. Пророк Илия. Фрагмент живописи иконы «Пророк Илия в житии» 1660-1662 гг. Федор Зубов и мастерская

надбровных дуг и переносицы, морщин на лбу, носогубных складок; узнаваемая графическая разделка волос (белые тончайшие нити на коричневом фоне, четкое деление каждого «уса» на малую и длинную пряди и т.д.). В образе Авраама, в сравнении с ликом Илии, заметно снижена степень экспрессивности, так как он, в отличие от пророка, не является «главным действующим лицом» произведения.

Причины необыкновенного эмоционального воздействия образа пророка Илии кроются среди прочего в некоторых специальных приемах изображения его лика. Хотя здесь речь идет, как и в ситуации с праотцем Авраамом, о трехчетвертном развороте, в данном случае формы активно сопротивляются необходимому при нем редуцированию: целиком показан «выглядывающий» левый глаз и почти полностью левая ноздря, которой вовсе не должно быть видно. Противоречие между ракурсом и пластикой усиливает драматизм образа. Описанного приема нет в изображении праотца Авраама, однако он (sic!) наличествует в образах ангелов с иконы «Святая Троица», что подтверждает предположение об использовании необычного «поведения» форм при трехчетвертном ракурсе для акцентирования 
внимания на «главных героях» произведения (рис. 10, 13). Для нас было неожиданным обнаружение сходства между совершенно разными ликами: убеленного сединами старца с иконы «Илия Пророк в житии» и дышащих красотой юности небесных вестников с иконы «Троица в деяниях». Особенно явственно оно ощутимо в изображении широко раскрытых глаз с нарочитой обводкой низа верхнего века, неочерченной, но лишь оттененной тоном верхней границей верхнего века, короткими выделенными стрелками по краям и прямоугольничками-слезниками, заполняющими лишь одну часть белка белильными треугольниками, наконец, с коротенькими ресничками.

Есть на иконе «Святая Троица» и женские образы: трижды изображена святая Сарра, а вдали - жена Лота, оборачивающаяся соляным столпом. Наиболее крупный из них - образ праведной Сарры на среднем плане, представленный в арке нарядной палаты. Самая близкая аналогия этому изображению от всего искусства XVII в. также обретается среди персонажей, населяющих иконы ярославской Ильинской церкви. Здесь в лике Богородицы с иконы «Вознесение Господне» мы встретим тот же S-образный манерный контур бровей, образующий трехлепестковую складку над переносицей, не овальный, а изломанный абрис лика, впечатление от которого усилено линией нависающего надо лбом изгибающегося плата без чепца (рис. 14, 15).

Особая роль в композиции гледенского шедевра отведена ритму, объединяю-

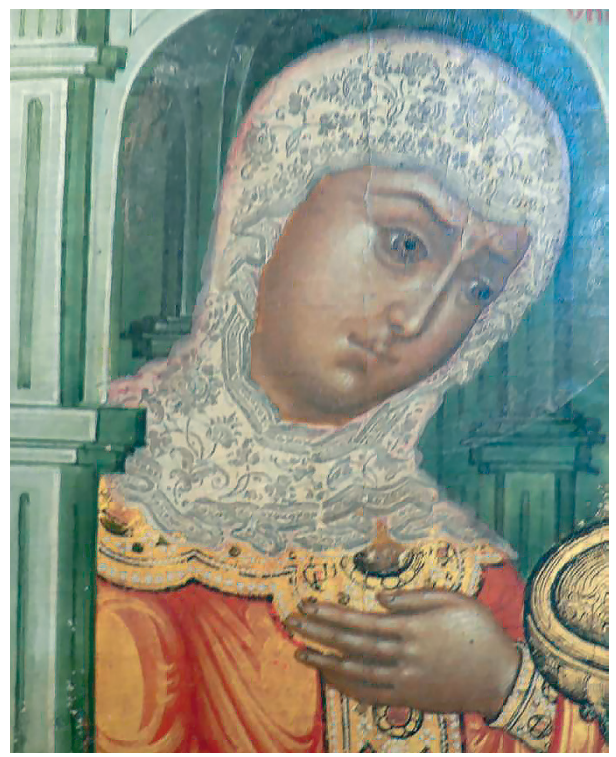

Рuc. 14. Праведная Сарра. Фрагмент живописи иконы «Святая Троица»

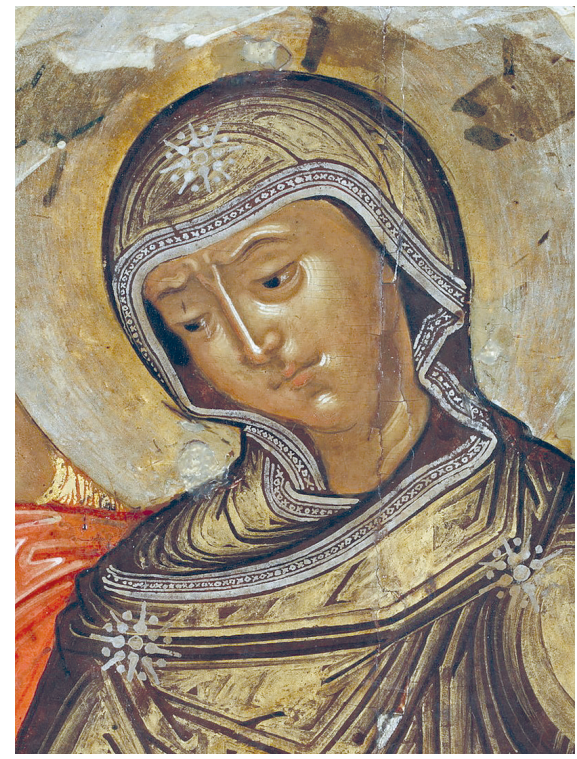

Рuc. 15. Богоматерь. Фрагмент живописи иконы «Вознесение Господне» 1660 1662 гг. Федор Зубов и мастерская

щему движение рук сидящих за столом ангелов. Эта ритмическая организация не имеет ничего общего с «рублевским» решением. Можно проследить, как от левой руки ангела, находящегося справа, к правой руке ангела, размещающегося слева, 
под очень низким углом восходит незримая линия, а затем, меняя свое направление в противоположную сторону, столь же плавно направляется к левой руке небесного вестника, сидящего в середине. Стоит отметить, впрочем, что пересекающиеся пологие диагонали - не только «каркас» данной части композиции, но и один из основных принципов построения композиции всей иконы. Руки странников, гостящих у Авраама, завораживают красотой своей формы. Крепкие, округлые, с короткими сильными пальцами, в их строении акцентирована каждая мышца, кругами обозначены суставы. Так писал руки святых и ангелов Федор Зубов. В поисках иконографико-стилевых аналогий для самых разных изображений рук на иконе «Святая Троица» мы вновь и вновь возвращаемся к ильинскому ансамблю начала 1660-х годов и находим аналогии для левой руки правого ангела в изображении левой руки апостола Петра из «Апостольской проповеди» (рис. 16, 17), для благословляющей десницы этого же ангела - в изображении указующей в небо руки ангела с иконы «Вознесение Господне» и правой руки Спасителя на иконе «Апостольская проповедь» (рис. 18, 19) etc.

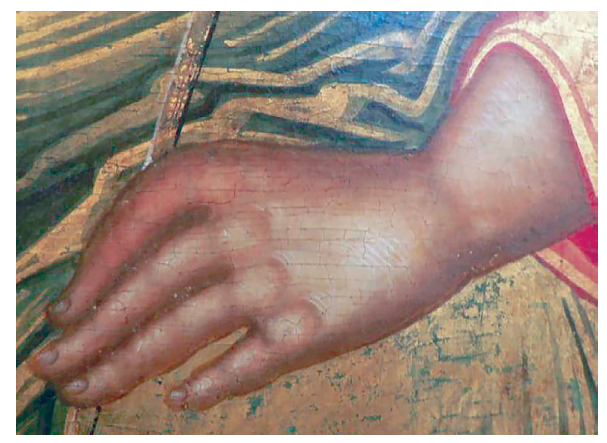

Рuc. 16. Рука ангела. Фрагмент живописи иконы «Святая Троица»

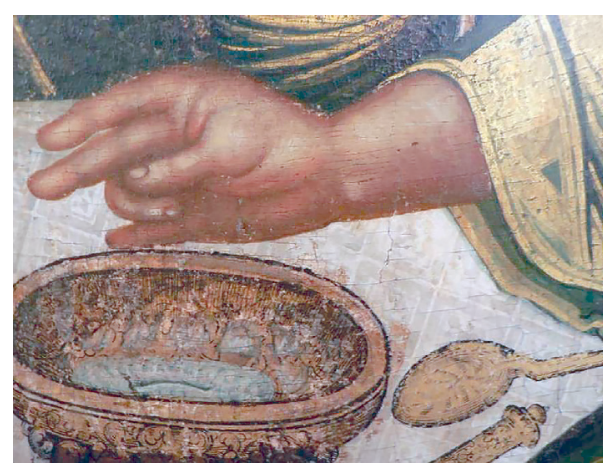

Рuc. 18. Рука ангела. Фрагмент живописи иконы «Святая Троица»

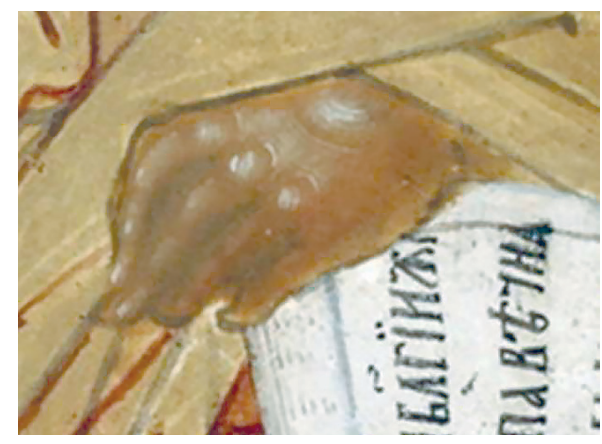

Рuc. 17. Рука апостола Петра. Фрагмент живописи иконы «Апостольская проповедь» 1660-1662 гг. Федор Зубов и мастерская

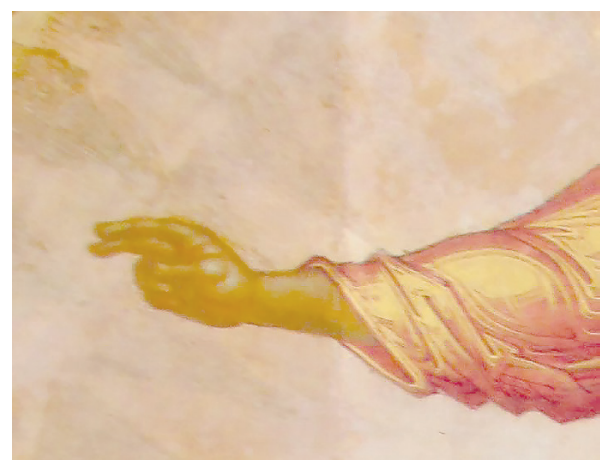

Puc. 19. Рука Спасителя. Фрагмент живописи иконы «Апостольская проповедь» 1660-1662 гг. Федор Зубов и мастерская 
На храмовой иконе Троицкого собора Троице-Гледенского монастыря вместо одной палаты представлен город, точнее, два города, один из которых - панорама Содома в верхнем правом углу. Стены палат светлы. В границах почти каждой плоскости цвет не лежит ровным тоном, но переливается, сгущаясь слева направо или в обратном направлении. Даже в местах наибольшей плотности он не образует глухого пятна, но сохраняет перламутровую прозрачность и светоносность. Три основных цвета, использованных в палатном письме: серебристо-зеленый, лиловорозовый и охра, - не были интересны мастеру как таковые, но лишь приведенные в тончайшую тоновую вибрацию. Тот факт, что цвет нигде не срывается в темноту, тем более примечателен, что архитектурный фон имеет сложное построение и насыщен деталями. Среди сотен форм хорошо прочитываются контуры центральной палаты, изображение которой определяет преемственность произведения по отношению к ранним версиям иконографии, в которых присутствовала лишь одна постройка. Эта связь остро ощущается благодаря лежащей в ее основе узнаваемой конструктивной схеме в виде портика с показанной в ракурсе боковой левой стенкой, уходящей по диагонали «вглубь и вниз» ${ }^{38}$. Портик аналогичной конфигурации различим в городском пейзаже некоторых других икон Святой Троицы в деяниях ${ }^{39}$.

Самая близкая иконографико-стилистическая параллель этим архитектурным построениям - палатное письмо образа «Благовещение Пресвятой Богородицы» из местного ряда церкви Пророка Ильи в Ярославле. Большое сходство чувствуется даже несмотря на то, что эта икона, как и все прочие ильинские образы начала 1660-х годов, написана заметно более бегло (рис. 20, 21). В основе изображения построек в «Благовещении» лежит уже знакомый нам «триколор» с нежными градациями в тоне, пусть и не такими изощренно-искусными, как на иконе Святой Троицы. В обоих случаях архитектурный декор, исполненный в цвет стены, разнообразен и тонок. Большие трапециевидные шатры увенчаны башенками и соседствуют с малыми шатрами-трапециями. Серебряные окошки имеют мелкую сетчатую расстекловку и углублены в затененные ниши, повторяющие их очертания. Дополнительными обрамлениями снабжены и иные проемы, а некоторые из них имеют трехлопастной абрис с центральной килевидной арочкой.

Рассматриваемый тип палатного письма восходит к работам строгановских иконописцев конца XVI - начала XVII в., в которых бытовала праформа, ставшая композиционной и колористической основой сложных архитектурных построений, присутствующих в живописи икон начала 1660-х годов из ярославской церкви Пророка Ильи и «Святая Троица» из Троице-Гледенского монастыря. В строгановских иконах мы находим «архитектурный» триколор, состоящий из бледных желтого, розового и зеленого, прорезанные арками палаты, их затененное в цвет стен нутро $^{40}$. В качестве промежуточного варианта укажем трактовку архитектурного фона мастером рамы с чудесами Богоматери Казанской второй четверти XVII в.,

38 Наиболее известная вариация такой формы портика - изображение палаты на иконе «Святая Троица» Андрея Рублева.

39 Примеры его изображения можно увидеть на иконе конца XVI в. из Ипатьевского монастыря [5, кат. 75]; второй половины XVII в. из церкви Покрова села Шунга [24, ил. 156, кат. 99] и этого же времени из церкви Усекновения главы Иоанна Предтечи в Ростове [23, кат. 103].

40 См. некоторые клейма иконы «Святой преподобный Максим Исповедник» из Благовещенского собора Сольвычегодска [42, кат. 29, ил. на с. 147], икону работы Никифора Истомина Савина «Чудо Святого Георгия о змие» первой половины XVII в. [53, ил. на с. 16]. 


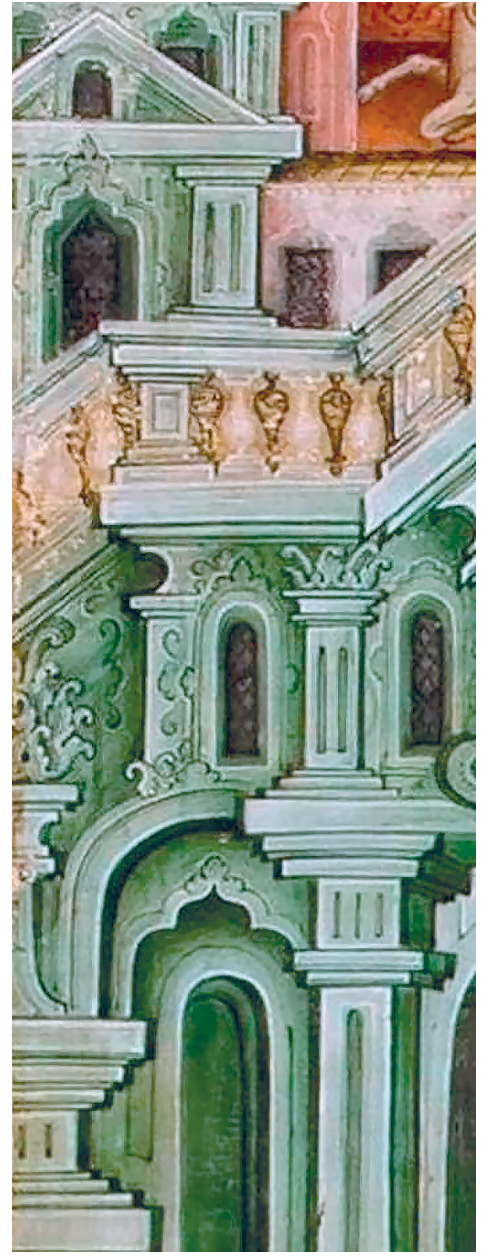

Puс. 20. Палаты. Фрагмент живописи иконы «Святая Троица»

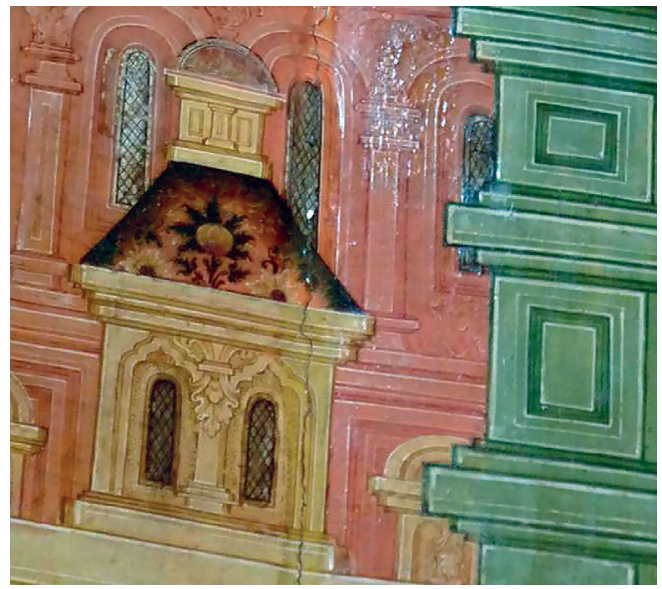

Puc. 21. Палаты. Фрагмент живописи иконы «Благовещение» 1660-1662 гг. Федор Зубов и мастерская

происходящей из Никольской церкви деревни Нюба (СИХМ) [42, кат. 63, с. 69-70, 187; 43, с.96-100], более сложную, чем на «строгановских» иконах рубежа XVI начала XVII в., но более простую, чем на иконах «Святая Троица» из Троице-Гледенского монастыря и на иконах Федора Зубова из ярославской Ильинской церкви (рис. 22). Здесь в клеймах палаты украшены широкими арками. Стены виднеющихся сквозь них покоев покрывает «черневой» узор из небольших завитков и цветов $^{41}$. В палатном письме нюбской рамы мы находим и знакомый колористический аккорд из светло-зеленого, розового и охристого, затенение ниш с градациями в тоне основного цвета, курчавый архитектурный декор фасадов и в нем - даже аналогичные килевидные арочки.

Художественный мир произведения богат разнообразным узорочьем, в обращении с которым проглядывает незаурядный талант иконописца. Мастер исполь-

41 Аналогичный черневой узор на стенах палат можно увидеть в сценах «Умовение Авраамом ног ангелам», «Заклание тельца» и «Испечение Саррой хлебов» иконы «Святая Троица» из ТроицеГледенского монастыря. 


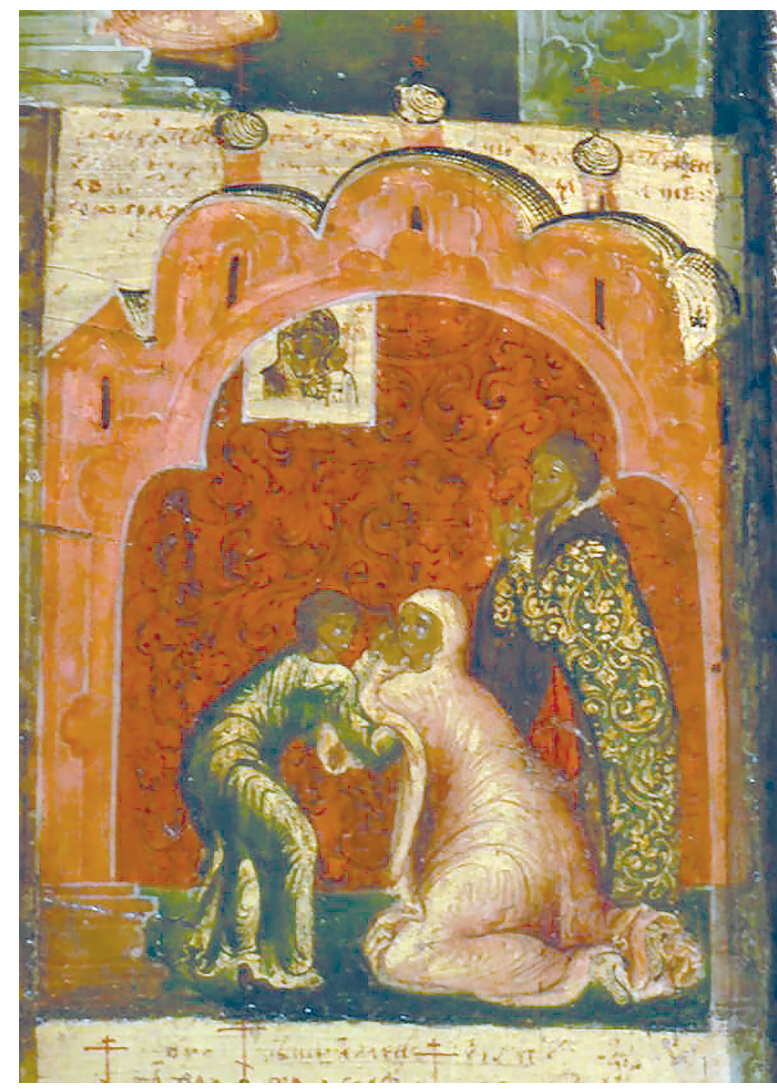

Puc. 22. Клеймо рамы с чудесами Богоматери Казанской. Вторая четверть XVII в.

зует его обильно и при этом никогда не дает ему свободы, не делает его самодовлеющим элементом формы. Узор повсюду подчинен предмету, на котором он выведен. В этом смысле очень красивы белые орнаментированные ткани: скатерть на столе и плат на голове Сарры. На плате мы находим сразу три типа узоров: ленту из О- и X-образных элементов, живописно разбросанные по поверхности цветы и над челом Сарры - орнаментальную ленту из чередующихся трилистников двух видов. На «вафельной» скатерти узоры формируют сетку, в каждый квадрат которой вписан четырехлепестковый цветок. По ее канту пущен ряд из парных стилизованных белых цветков двух типов. Узоры на плате и скатерти бесцветные: серые на белом или наоборот. Бледные, не сразу различимые, они удивляют изяществом, тонкостью исполнения, напоминают морозные разводы на стекле. Подобные приемы изображения светлых тканей со светлыми же узорами были хорошо известны в искусстве Великого Устюга середины XVII ст. Чтобы в этом убедиться, достаточно вспомнить охристый омофор с полупрозрачными белыми кругами, заполненными легкими стеблями с небольшими листиками, на уже упоминавшейся выше небольшой иконе «Святитель Николай Чудотворец» (ВУМЗ), приписываемой Федору Зубову, и образ «Спас Нерукотворный» (ВУМ3), где плат покрыт частыми полосками, между которыми рядами «высыпаны» мелкие золотые точки (рис. 8). 


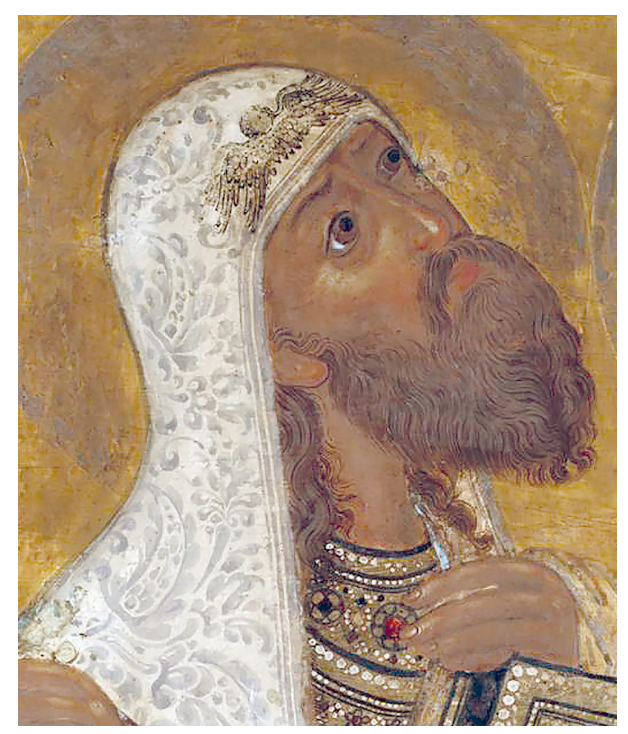

Рuc. 23. Святитель Леонтий Ростовский. Фрагмент живописи иконы «Святители в предстоянии «Богоматери Знамение» 1660-1662 гг. Федор Зубов и мастерская
И все же наиболее близкую трактовку изображения драпировок мы находим в живописи ансамбля начала 1660 -х годов из церкви Ильи Пророка в Ярославле. На иконе «Святители в предстоянии Богоматери Знамение» по белой, без единой складочки ткани клобуков святителя Леонтия Ростовского, митрополитов московских Петра и Алексия разбросаны серебряные цветки (рис. 23, 14) ${ }^{42}$. При работе по заказу Скрипиных Федор Зубов использовал в украшениях одежд популярную в XVII в. орнаментальную полосу из Ои X-образных элементов. Данный мотив можно увидеть на иконах «Богоматерь Владимирская» Истомы Елизарова первой четверти XVII в. (СГИХМ) [42, кат. 37, ил. на с. 156], «Богородица» из трехчастного Деисуса середины XVII в. из Троицкого собора Ипатьевского монастыря [24, ил. 82. кат. 61], «Преподобный Иосиф Волоцкий

в молении перед Богоматерью» 50-60-х годов XVII в. из Иосифо-Волоколамского монастыря (ГРМ) [39, ил. на с. 135], «Святитель Николай» последней четверти XVII в. из церкви Воскресения села Остров Гаврилов-Ямского района Ярославской области (ЯХМ) [28, кат. 113, ил. на с. 139]. Он украшает омофор святителя Николая на иконе из Великоустюгского музея. Всякий раз мотив приобретал особую трактовку, его детали могли истончаться, а сам он образовывал то ровную полосу, то вьющуюся ленту. В этом смысле орнаментальный ряд, декорирующий плат Сарры на иконе «Святая Троица» из Гледенского монастыря, находит ближайшую аналогию в изображении узоров на рубашках ангелов и по канту мафория Богоматери на иконе «Вознесение Господне» из Ильинского храма: орнамент показан серебряным, заключен в двойную рамку из тонкой внутренней и более широкой внешней полосы и идет не прямо, но извиваясь и перекручиваясь косичкой ${ }^{43}$.

Изображение природы на иконе «Ветхозаветная Троица» из Троице-Гледенского монастыря - одно из самых красивых во всем древнерусском искусстве XVII ст. «Дворец» Авраама, город, окружающий этот дворец, фигуры мастерски вписаны в пейзажное окружение. Несмотря на многообразие мотивов (здесь присутствуют скалы, поля, лес, высокий дуб, цветы), благодаря особенностям техники письма пейзаж воспринимается как целостная среда. Вся отведенная под «горки» живописная поверхность была сплошь залита охрой одного колера, затем пролессирована прозрачными белилами, за счет чего цвет земли приобрел холодноватый оттенок. Далее при помощи цветных притенений (красным и зеленым) и ударов

42 Клобуки на иконе «Святители в предстоянии иконе Богоматери Знамение» и плат Сарры с иконы «Ветхозаветная Троица» схоже очерчены понизу толстой серебряной полосой. Цветочные узоры на плате Сарры мельче, выписаны тщательнее и дополнены орнаментальной лентой.

43 Этот же узор находим в отделке одежд святых с иконы «Апостольская проповедь». 
кисти чистыми белилами мастером были созданы разные фактуры: «близкая» песчаная земля под ногами ангелов, зеленый луг в сцене «Жертвоприношение Авраама», наконец, вздымающиеся ввысь скалы в правом верхнем углу, где тени и пробела наиболее интенсивны. С землей по цвету контрастирует изумруднозеленая листва деревьев, с глубокими тенями и золотой корой. Кряжистые ветви несут на себе мощные кроны. Форма кроны Мамврийского дуба моделирована горизонтальными штрихами ${ }^{44}$. В композицию деликатно введены изображения крупных, отдельно растущих цветков, изысканных по колористическому решению. Неяркие, бледно-зеленые с лиловым и белым, они напоминают прозрачных медуз $(\text { рис. } 6,24)^{45}$.

В иконописи XVII ст. можно найти некоторые параллели отдельным мотивам, присутствующим в пейзаже гледенской «Троицы». Вновь аналогии обнаруживаются в живописи икон из местного ряда церкви Ильи Пророка в Ярославле. Сходство заметно, несмотря на бо́льшую обобщенность, даже упрощенность приемов, которыми оперировали Федор Зубов и его помощники, трудясь по заказу Скрипиных. На иконе «Апостольская проповедь» из Ильинского хра-

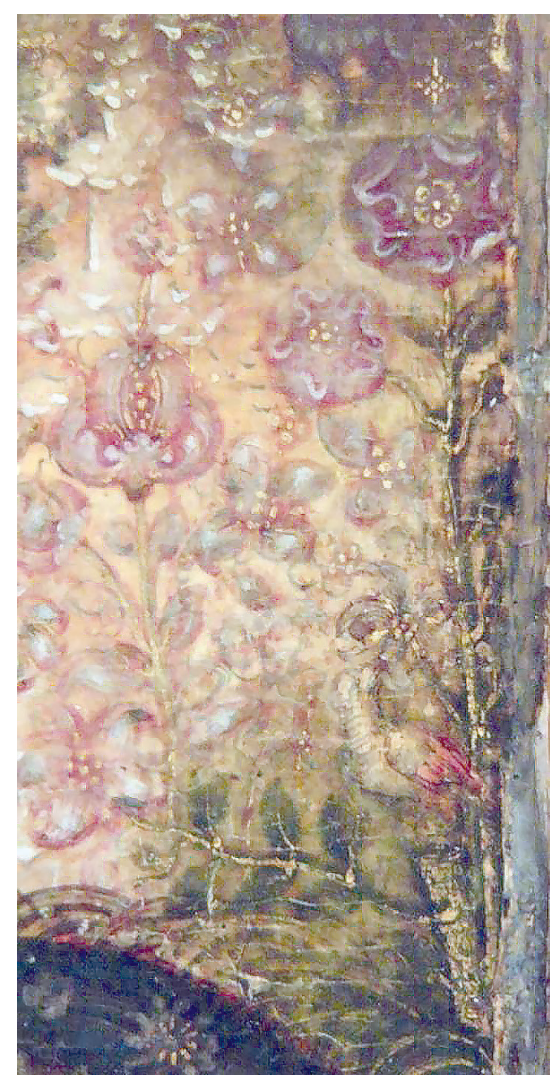

Puc. 24. Фрагмент пейзажа с иконы «Святой Иоанн Предтеча». Середина XVII в. ГТГ ма весь фон внутри сферы прописан охрой, горки притенены зеленым и коричневым, а сгущенная в тоне в сравнении с тенью линия их контура словно пускает корни в тело горок. Близкое построение лещадок можно наблюдать на иконах «Вознесение Господне», «Илья Пророк в деяниях» и на раме с «Акафистом Богородице» ${ }^{46}$. На иконе «Вознесение» совмещены изображения скалистой земли и зеленых лугов с рощами.

44 Аналогичный прием, напоминающий штрихи на гравюрах, присутствует в изображении листвы деревьев на ильинских иконах.

45 При разговоре о пейзаже, представленном на гледенской иконе «Святая Троица», вспоминается уже упоминавшийся в настоящей статье образ «Святой Иоанн Предтеча» (ГТГ), который В.Г.Брюсова приписывает кисти Федора Зубова. В ней можно обнаружить не только аналогично трактованные горки и рощу с золотыми стволами, но даже, казалось бы, уникальные по цвету и по форме похожие на медузы цветы, украсившие икону Святой Троицы из Троицкого Гледенского монастыря.

46 У таких лещадок почти никогда нет вершин. Из нижележащих лещадок вырастают вертикальные грани, служащие основанием для следующих. У каждой лещадки имеется только нижний край, как правило, неровный, составленный из нескольких положенных рядом не в одной плоскости полосок белил. Таким образом, формы не замыкаются, но постоянно вскрываются, благодаря чему создается впечатление подвижности почвы. 


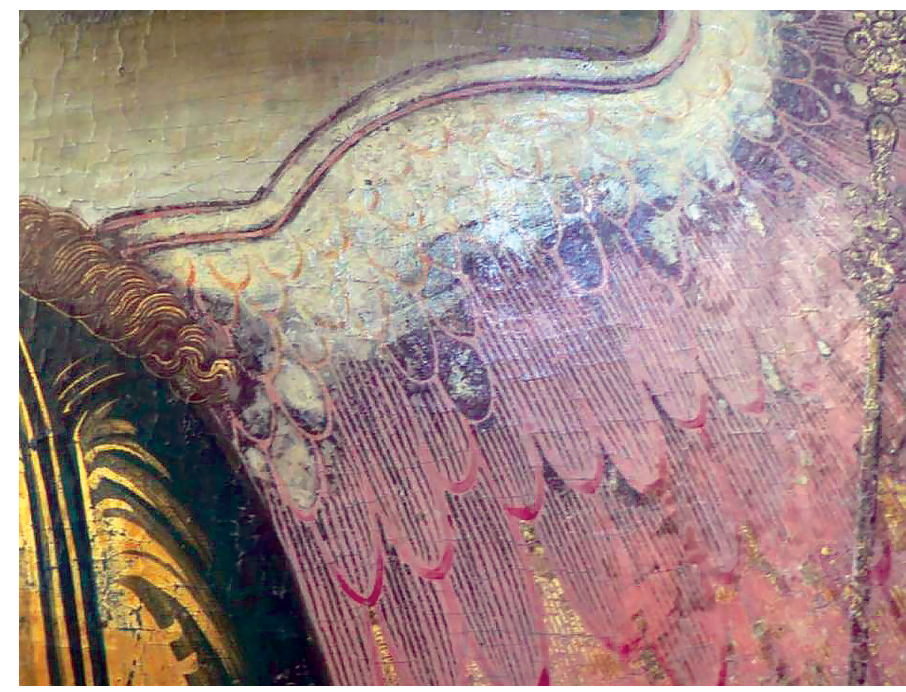

Puc. 25. Крыло ангела. Фрагмент живописи иконы «Святая Троица»

Завораживают в гледенской «Троице» ангельские крылья, подобных которым нет ни на одной другой иконе (рис. 25). Их живопись производит сложное впечат-

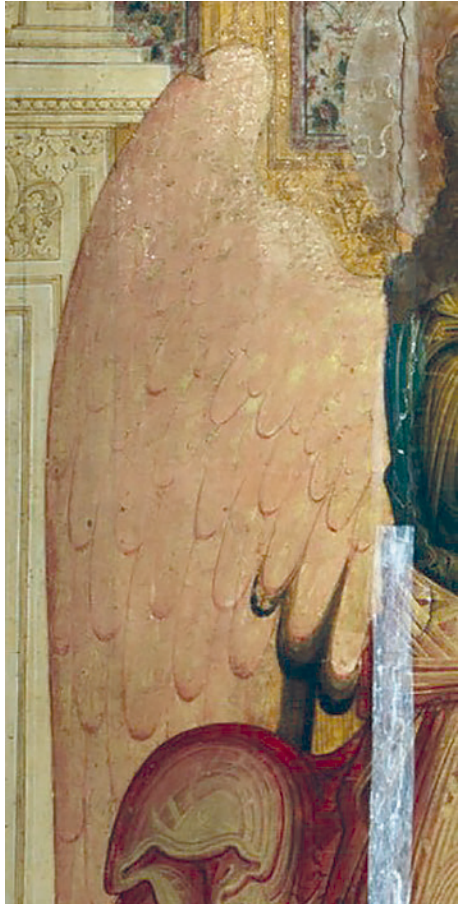

Рuc. 26. Крыло архангела Гавриила. Фрагмент живописи иконы «Благовещение» 1660-1662 гг. Федор Зубов и мастерская ление. Здесь легкость сочетается с силой, ирреальная красота - с осязаемой энергией. Каждое длинное перышко внутренней нежно-розовой части крыл покрыто частыми параллельными золотыми штрихами. Белые кроющие перышки меньшего размера в верхней их части сформированы в орнаментальный ряд из треугольников. Плечи и предплечья крыльев мастер своеобразно выделил, придав им вид белой четко очерченной змеевидной ленты. Краски, использованные при написании крыл (красная, розовая, белая), тают в свечении ассистных лучей, что придает им огнеподобный вид.

В более лаконичной форме описанную выше систему изображения крыльев можно найти на иконе «Благовещение» из церкви Ильи Пророка, на которой архангел показан со светло-розовыми крыльями, покрытыми нитями ассиста, и сформированными в ряд треугольников малыми перышками вверху (рис. 26). Но самой близкой иконографической параллелью гледенской «Троице» в этом отношении является образ «Иоанн Предтеча - Ангел пустыни» Федора Зубова середины XVII в. из Антониево-Сийского монастыря (ГМЗРК) (рис. 27). По счастью, с этой иконы в XVII ст. была снята точная прорись, сохранившаяся в составе Сийского ико- 


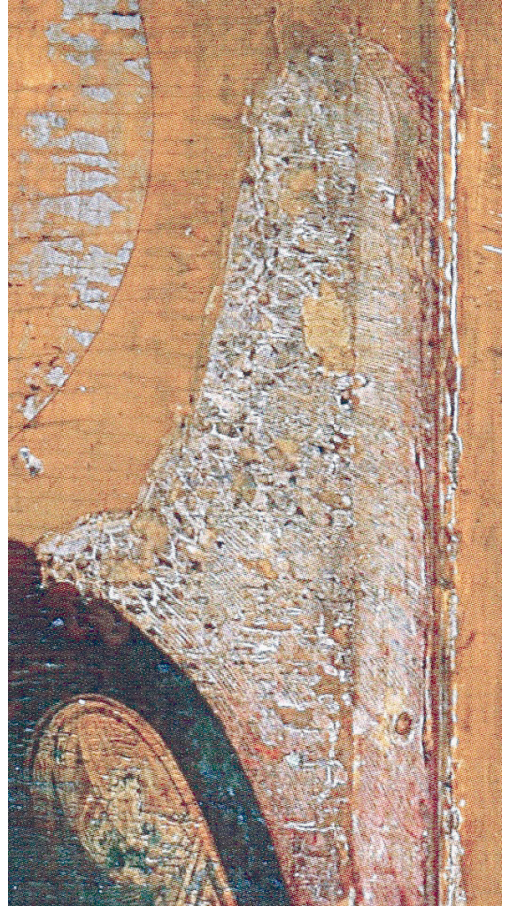

Рuc. 27. Фрагмент живописи иконы «Иоанн Предтеча - Ангел пустыни». Федор Зубов. Середина XVII в.

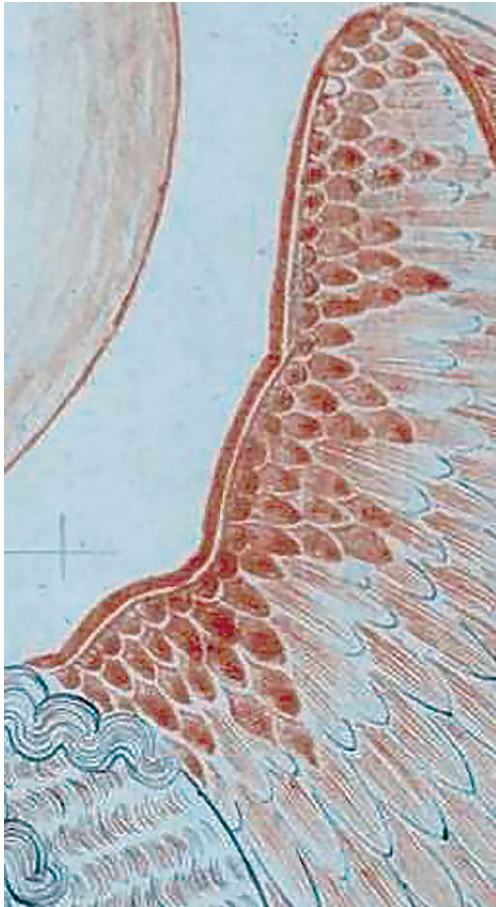

Рис. 28. Фрагмент прориси с иконы Федора Зубова «Иоанн Предтеча - Ангел пустыни»

нописного подлинника (рис. 28) [54, л. 221], которая позволяет составить представление о первоначальном виде показанных на иконе крыл. В произведении из Антониево-Сийского монастыря прочитывается во всей сложной полноте структура живописи крыльев, так удивляющая в гледенской «Троице». Тут и сложенные треугольниками перышки, и упругая графика контура крыльев. Степень близости, как нам представляется, простирается за границы иконографии (и за пределы иконографии крыльев), но позволяет говорить о большом сходстве образно-художественной природы двух икон.

В живописи гледенской «Троицы», в которой так много уникальных черт складываются в оригинальную художественную целостность, мы найдем все основные приметы стиля икон Федора Зубова из церкви Ильи Пророка в Ярославле: тот же модуль соотношения тяжелой пластики, грузной формы с орнаментом и элементами графики, перепады пространства, смелый колорит, необычайная темпераментность авторской манеры, даже аналогичная работа с изобразительными источниками ${ }^{47}$. Для характеристики этого стиля нам представляется показательным

47 Здесь мы имеем в виду факт использования Федором Зубовым при создании ансамбля икон начала 1660-х годов для Ильинского храма гравюр Библии Пискатора, на который обратила внимание Т.Е. Казакевич [37, с.53], и обращение к этим гравюрам мастера Гледенской «Святой Троицы». В своей статье Т.Е. Казакевич писала: «Присущий перечисленным выше иконам “фряжский” стиль получил наиболее законченное выражение в иконе “Апостольская проповедь”, где знаменщик почти целиком построил свою композицию на основе гравюр Библии Пискатора». 
один пример. В числе близких иконографических аналогий иконе «Ветхозаветная Троица» из Великоустюгского музея исследователями указывался одноименный образ 1659 г. из церкви Троицы в Никитниках (рис. 1, 3, 29). На обеих иконах

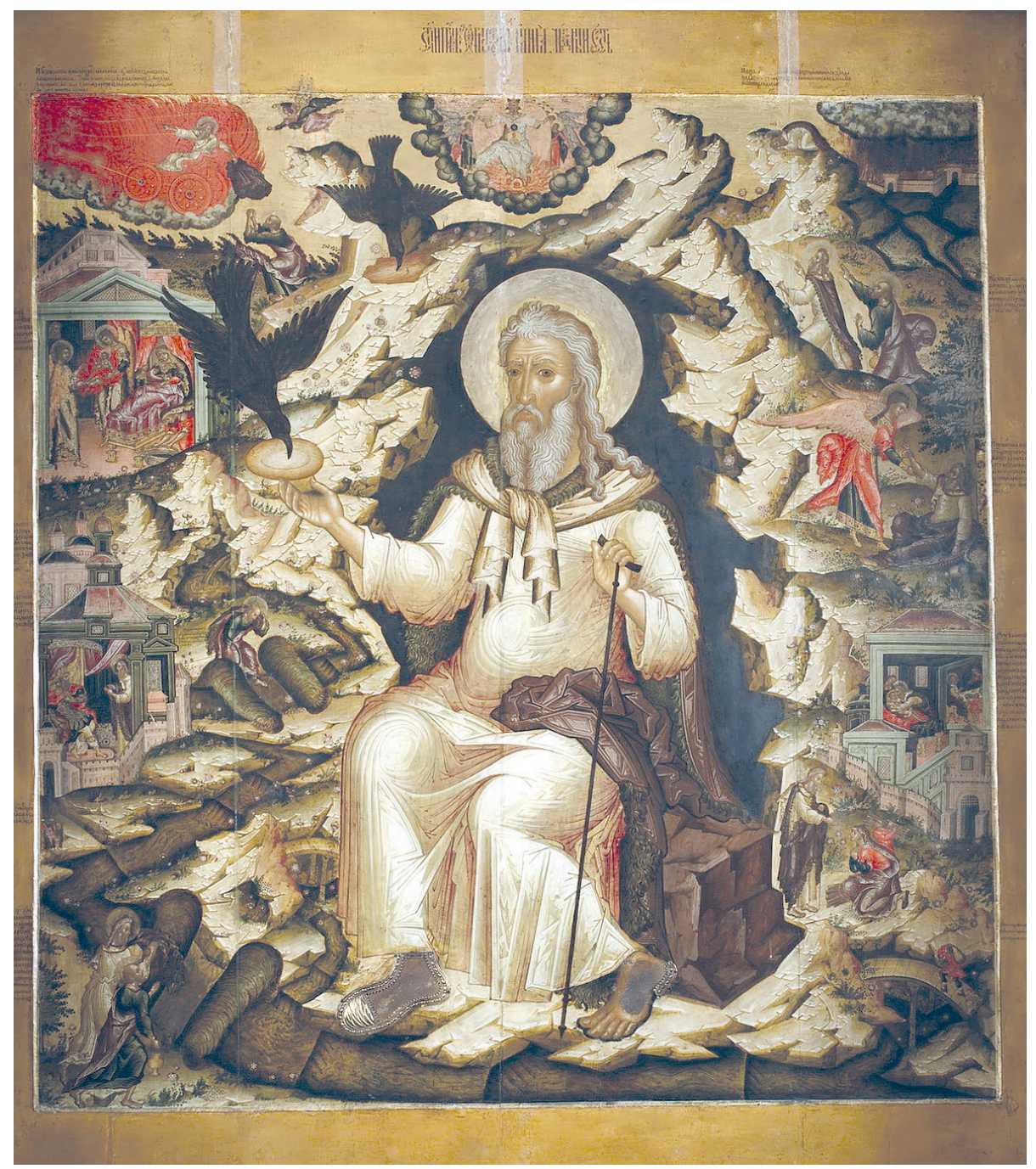

Puc. 29. Пророк Илия в житии. Икона 1660-1662 гг. Федор Зубов и мастерская

горки с одной стороны и палаты с другой вздымаются почти до самого верхнего поля. Однако в решении этой части композиции двумя мастерами есть сущностное различие. На иконе из Никитников то, что находится наверху: палата с Саррой и город, - принадлежит вертикальной плоскости. В схожей ситуации мастер гледенской «Троицы» использовал тот же прием, который можно наблюдать воплощенным в живописи иконы «Святой Пророк Илия в житии» из церкви Ильи Пророка в Ярославле. В сценах, расположенных в верхних углах икон «Пророк Илия» и «Троица», взгляду, поднявшемуся на высоту, вдруг открывается дальняя горизонтальная перспектива, пространство прорывается вглубь. 
Таким образом, по своему стилю икона из Троицкого Гледенского монастыря находит аналогии среди целого круга произведений иконописи XVII ст. Наиболее близкими из них оказываются иконы, которые с большей или меньшей степенью вероятности приписывают кисти Федора Зубова, причем иконы, относящиеся к определенному этапу развития его авторской манеры. Имеется в виду «предмосковская» ступень ее эволюции, пришедшаяся на 1650-е - начало 1660-х годов. Федор Зубов, уроженец Усолья Камского, сформировавшийся как изограф в традициях позднестрогановского местного иконописания, бывал в Москве на царских работах еще до 1645 г., но окончательно поселился в столице лишь в 1662 г. и жил здесь до своей смерти в 1689 г. В Москве он воспримет искусство «ушаковского» типа, в том числе новую физиогномику ликов, голубые фоны, и, хотя яркое авторское начало будет проявляться также в поздних его работах ${ }^{48}$, по сумме своих стилистических признаков произведения «московского» периода говорят о наступлении в его творчестве «живоподобной» стадии.

В оригинальном художественном мире «Святой Троицы» приметы «роскошного» стиля облеклись чертами самобытной авторской манеры. Анализируя разные его составляющие, от типологии ликов, формы кистей рук, трактовки очертаний причесок и горок до характера орнаментальных мотивов и доступных для визуального восприятия технико-технологических особенностей живописи, мы вновь и вновь приходили к атрибутированным иконам кисти Федора Зубова и его круга, созданным в начале 60-х годов XVII ст. Данные стилистического анализа не противоречат атрибуции иконы как произведения конца 1650-х годов кисти Федора Зубова. За неимением документального подтверждения атрибуция должна рассматриваться в качестве гипотезы, хотя вероятность того, что в Великом Устюге XVII в. творил другой мастер, равный Федору Зубову не только своим творческим «стилевым» кредо, но и талантом, крайне мала.

Благодаря опубликованному О.А. Белобровой документу известно, что в Великом Устюге была «Троица» Федора Зубова [55]. Интересно, что в «Росписи устюжанина Васки Леонтьева Колмогорова святым иконам» «Образ Пресвятыя Троицы, работа Федора Евътифиева, оклад чеканной белой» $[55$, с. 170, 174] (наличие оклада - признак, говорящий о невозможности отождествить упоминающийся образ с гледенской «Троицей») перечисляется наряду с другими иконами, среди которых работа Сергия-монаха «Вознесение Господне», вероятно, того самого гледенского монаха, который написал для своего монастыря «Успение» и «Сошествие Святого Духа» ${ }^{49}$.

Представляется, что «Святая Троица» из Троицкого собора Троице-Гледенского монастыря была создана мастером, имевшим отношение к царской иконописной мастерской «доушаковского» времени, но воспитанным в традициях местного иконописания, культивировавшегося изографами Сольвычегодска и Великого Устюга. Икона была написана одним из ведущих изографов эпохи, впитавшим в свое творчество все лучшее, что могла дать его художественная среда.

48 Например, в живописи иконы «Рождество Богоматери» 1688 г. (МиАР).

49 Сведения о том, что Сергий был иноком гледенской обители, можно почерпнуть из надписи на иконе «Успение Богоматери», где сообщается о написании образа в Троицком монастыре «тое же обители многогрешным монахом, изуграфом Сергием». 


\section{Литература}

1. Савваитов П. И. Описание Великоустюжского архангельского и приписного к нему Троицкого Гледенского монастырей. СПб.: Тип. кн. маг. П. Крашенинникова и комп., 1848. 62 с.

2. Сорокатый В.М. Храмовая икона Успенского собора Великого Устюга // ДРИ. Художественные памятники Русского Севера. М.: Наука, 1989. С. 181-192.

3. Возрожденные шедевры Русского Севера. Исследование и реставрация памятников художественной культуры Вологодской области. Выставка, посвященная 850-летию Москвы, Вологды и Великого Устюга и 600-летию Кирилло-Белозерского и Ферапонтова монастырей. 17 октября 1997 - 25 января 1998. Вологда, М.: Галарт, 1998. 166 с.

4. Искусство земли вологодской XIII-XX веков. Каталог выставки / под ред. И. Я. Богуславской, Ю.Э. Осмоловского и А. А. Рыбакова. М.: Советский художник, 1990. 263 с.

5. Преподобный Сергий Радонежский и образ Святой Троицы в древнерусском искусстве. Каталог выставки. 10 декабря 2013 - 10 февраля 2014 / сост. Г. В. Попов, Н. И. Комашко. М.: Красная площадь, 2013. 189 с.

6. Соловьева И. Д., Мальщев Н. В. Иконостас Троицкого собора Троице-Гледенского монастыря. Тверь: Верхов С. И., 2014. 29 с.

7. Шильниковская В. П. Великий Устюг. Развитие архитектуры города до середины XIX в. Издание второе. М.: Стройиздат, 1987. 254 с.

8. Титов А.А. Летопись Великоустюжская по Брагинскому списку XIII-XX вв. М.: Издание К.Н.Брагина, 1903. 81 с.

9. Зенкова О.Б. Троице-Гледенский монастырь. Великий Устюг: ВУМЗ, 2007. 21 с.

10. Акты Холмогорской и Устюжской епархий. Часть вторая. СПб.: Русская Историческая библиотека, 1894. $1286 \mathrm{c}$.

11. Тихонов Ю. А. Рынок Устюга Великого в середине XVII века // Исторические записки. Вып. 39. М.: Изд-во АН СССР, 1952. С. 204-228.

12. Акты Холмогорской и Устюжской епархий. Часть первая. 1500-1699 гг. СПб.: Русская историческая библиотека, 1890. 1645 с.

13. Мальцев Н. В. Скульптурный декор иконостасов Великого Устюга // ПКНО. 1977. М.: Наука, 1977. C. 282-295.

14. ВУФ ГАВО. Ф.436. Великоустюгский Михайло-Архангельский мужской монастырь. Оп. 1. Д. 114.

15. ВУФ ГАВО. Ф.363. Великоустюгская духовная консистория. Д. 787. Опись церковных предметов хозяйственного инвентаря Троицко-Гледенского монастыря за 1754 г.

16. Евдокимов И. В. Север в истории русского искусства. Вологда: Союз сев. кооп. союзов, 1921. $230 \mathrm{c}$.

17. Мерзон А.Ц., Тихонов Ю.А. Рынок Устюга Великого в период складывания всероссийского рынка (XVII век). М.: Изд-во АН ССCР, 1960. 715 с.

18. Дедюхина В. С., Рузавин Ю. А. История создания и реставрации иконостаса Троицкого собора Гледенского монастыря г. Великого Устюга // Художественное наследие. Хранение, исследование и реставрация. Вып. 6 (36). М.: Искусство, 1980. С. 193-202.

19. Изобразительное искусство и художественная культура Русского Севера конца XIV - начала XXI века. Новые открытия российских реставраторов. Каталог выставки, посвященной 25-летию Вологодского филиала ВХНРЦ имени академика И.Э. Грабаря. Вологда: Арника, 2012. 152 с.

20. Словарь русских иконописцев XI-XVII веков / ред.-сост. И.А. Кочетков. М.: Индрик, 2009. $1102 \mathrm{c}$.

21. Вилинбахова Т.Б. Икона XVI века «Троица в деяниях» и ее литературная основа // ТОДРЛ. T. XXXVIII. Л.: Наука, 1985. С. 126-137.

22. Нерсесян Л. В., Комашко Н.И. Образ Троицы в русском искусстве Позднего Средневековья и переходного времени // Преподобный Сергий Радонежский и образ Святой Троицы в древнерусском искусстве. Каталог выставки. М.: Красная площадь, 2013. С.28-35.

23. Вахрина В. И. Иконы Ростова Великого. М.: Северный паломник, 2006. 447 с.

24. Костромская икона XIII-XIX веков / авт.-сост. Н.И.Комашко, С.С.Каткова. М.: ГрандХолдинг, 2004. 672 c.

25. Рыбаков А.А. Вологодская икона. Центры художественной культуры земли Вологодской XIII-XVIII веков. М.: Галарт, 1995. 435 с.

26. Икона Святой Троицы царского изографа Кирилла Уланова / ред.-сост. И.А.Шалина. М.: МРИ, 2015. 125 c. 
27. Куликова О. В. Древние лики Русского Севера. Из музейного собрания икон XIV-XIX веков города Череповца. М.: Гранд-Холдинг Магма, 2009. 245 с.

28. Ярославский художественный музей. Каталог собрания икон / авт.-сост. О.Б.Кузнецова; науч. ред. И. Л. Бусева-Давыдова. Ярославль: Издательское бюро «ВНД», 2012. Т. II, ч. 2. 304 с.

29. Псковская икона XIII-XVI веков / авт.-сост. И. С. Родникова. Л.: Аврора, 1990. 323 с.

30. Добрынин С. Н. Реставрация иконы XVII века «Святая Троица, со сценами бытия» // Наследие Холмогорской земли XVI - начала XX века в музеях Архангельской области / авт.-сост. Т. М. Кольцова. М.: СканРус, 2011. С. 114-117.

31. Божественные гимны преподобного Симеона Нового Богослова. М.: Правило веры, 2006. $718 \mathrm{c}$.

32. Русские монастыри. Искусство и традиция. СПб.: Palace Edition, 1997. 239 с.

33. Тельтевский П.А. Великий Устюг. Архитектура и искусство XVII-XIX веков. М.: Искусство, 1977. $179 \mathrm{c}$.

34. Брюсова В. Г. Русская живопись XVII века. М.: Искусство, 1984. 338 с.

35. Данилова И.Е., Мнева Н.Е. Живопись XVII века // История русского искусства / под ред. И.Е. Грабаря. М.: АН СССР, 1959. T.IV.С. 345-466.

36. Болотцева И.П. Ярославская иконопись второй половины XVI-XVII веков. Ярославль: Изд-во Александра Рутмана, 2004. 173 с.

37. Казакевич Т.Е. Иконостас церкви Ильи Пророка и его мастера // Памятники русской архитектуры и монументального искусства. М.: Наука, 1980. С. 13-64.

38. Иконописцы царя Михаила Романова / сост. В. А. Меняйло. М.: Художник и книга, 2007. 179 с.

39. Древлехранилище памятников иконописи и церковной старины в Русском музее. Альманах. СПб.: Palace Editions, 2014. Вып. 433. 208 с.

40. Святая Русь. Альманах. СПб.: Palace Editions, 2011. Вып. 302. 496 с.

41. Овчинникова E.C. Церковь Троицы в Никитниках. Памятник живописи и зодчества XVII века. М.: Искусство, 1970. 196 с.

42. Иконы строгановских вотчин XVI-XVII веков. По материалам реставрационных работ ВХНРЦ имени академика И.Э.Грабаря. Каталог-альбом. М.: Сканрус, 2003. 439 с.

43. Чугреева Н. Н. Казанский образ Богоматери в произведениях строгановских мастеров // Культурное наследие Русского Севера: память и интерпретации. К 90-летию Сольвычегодского историко-художественного музея. СПб.: Пушкинский Дом, 2009. С. 92-100.

44. Россия. Православие. Культура. Каталог выставки. Ноябрь 2000 - февраль 2001. М.: Коллекция М; Типография Новости, 2000. 304 с.

45. Полякова О.А., Послыхалина М.В. Подписные и датированные иконы в собрании Московского государственного объединенного музея-заповедника Коломенское - Измайлово - Лефортово - Люблино. М.: МГОМЗ, 2013. 156 с.

46. Меняйло В.А. Иконы Чудова монастыря Московского Кремля. Каталог. М.: ГММК, 2015. $483 \mathrm{c}$.

47. Брюсова В. Г. Федор Зубов. М.: Изобразительное искусство, 1985. 208 с.

48. Брюсова В.Г. Неизвестные произведения Федора Зубова // ПКНО. 1979. Л.: Наука, 1980. C. 256-267.

49. Болотиева И. П. Новое о творчестве живописца XVII века Федора Евтихиева Зубова // ГММК. Материалы и исследования. М.: Искусство, 1984. С. 117-132.

50. Бусева-Давыдова И. Л. Симон Ушаков и русская культура второй половины XVII века // Симон Ушаков - царский изограф. М.: ГТГ; МРИ, 2015. С. 10-23.

51. Бекенева Н. Г., Нерсесян Л. В. Симон Ушаков. Жизнь и творчество // Симон Ушаков - царский изограф. М.: ГТГ; МРИ, 2015. С. 24-39.

52. Комашко Н. И. Симон Ушаков и сложение нового стиля русской иконописи // Симон Ушаков - царский изограф. М.: ГТГ; МРИ, 2015. С. 40-51.

53. Иконы из коллекции Сергея Григорьевича Строганова / авт.-сост. Т. Б. Вилинбахова, Н. В. Пивоварова. СПб.: Palace Edition, 1996. 24 с.

54. РНБ. ОЛДП. F. 88. Сийский иконописный подлинник.

55. Белоброва О. А. К биографии «Государева иконника» Федора Евтихиева Зубова // ДРИ. Рукописная книга. Сб. второй. М.: Наука, 1974. С. 168-174.

Для цитирования: Западалова П.В. Икона «Святая Троица со сценами Бытия» из ТроицеГледенского монастыря // Вестник СПбГУ. Искусствоведение. 2017. Т. 7. Вып.2. С. 168-202.

DOI: $10.21638 / 11701 /$ spbu15.2017.204 


\section{References}

1. Savvaitov P. I. Opisanie Velikoustuzhskogo arkhangel'skogo i pripisnogo k nemu Troitskogo Gledenskogo monastyrei [Savvaitov P.I.Description of the Archangel Monastery in Veliky Ustyug and related to them Troitse-Gledensky Monastery]. St. Petersburg, Tip. kn. mag. P. Krasheninnikova i komp., 1848. 62 p. (In Russian)

2. Sorokatyi V. M. Khramovaia ikona Uspenskogo sobora Velikogo Ustiuga [The Main Icon of the Dormition Cathedral in Veliky Ustyug]. DRI. Khudozhestvennye pamiatniki Russkogo Severa [Ancient Russian Art. The Monuments of Russian North]. Moscow, Nauka Publ., 1989, pp. 181-192. (In Russian)

3. Vozrozhdennye shedevry Russkogo Severa. Issledovanie i restavratsiia pamiatnikov khudozhestvennoi kul'tury Vologodskoi oblasti. Vystavka, posviashchennaia 850-letiiu Moskvy, Vologdy i Velikogo Ustiuga i 600-letiiu Kirillo-Belozerskogo i Ferapontova monastyrei. 17 oktiabria 1997 - 25 ianvaria 1998 [Restored Masterpieces of Russian North. Research and restoration of the cultural monuments in the Vologda Oblast. An exhibition, devoted to the 850 th anniversary of Moskow, Vologda and Veliky Ustyug and to the $600^{\text {th }}$ anniversary of the Kirillo-Belozersky and Ferapontov Monastery. 17 $7^{\text {th }}$ October $1997-25$ january 1998]. Vologda, Moscow, Galart Publ., 1998. 166 p. (In Russian)

4. Iskusstvo zemli vologodskoi XIII-XX vekov. Katalog vystavki [Art of the Vologda area in the $13^{\text {th }}-19^{\text {th }}$ centuries]. Eds I. Ia. Boguslavskaya, Iu. E. Osmolovsky, A. A. Rybakov. Mosvow, Sovetskii khudozhnik Publ., 1990. $263 \mathrm{p}$.

5. Prepodobnyi Sergii Radonezhskii i obraz Sviatoi Troitsy $v$ russkom iskusstve. Katalog vystavki. 10 dekabria 2013 - 10 fevralia 2014 [Saint Sergius of Radonezh and the image of Saint Trinity in Russian art. Catalogue of the exhibition. 10 december - 10 february 2014]. Comp. G. V. Popov, N. I. Komashko. Moscow, Krasnaia ploshad' Publ., 2013. 189 p. (In Russian)

6. Solov'eva I.D., Mal'tsev N.V. Ikonostas Troitskogo sobora Troitse-Gledenskogo monastyria [Iconostasis of the Trinity Cathedral of the Troitse-Gledensky monastery]. Tver, Verkhov S. I. Publ., 2014. 29 p. (In Russian)

7. Shil'nikovskaia V.P. Velikii Ustiug. Razvitie arkhitektury goroda do serediny XIX v. Izdanie vtoroe [Veliky Ustyug. Development of the town architecture until the middle of the $19^{\text {th }}$ century. Second Edition]. Moscow, Stroiizdat, 1987. 254 p. (In Russian)

8. Titov A. A. Letopis' Velikoustiuzhskaia po Braginskomu spisku XIII-XX vv. [The Veliky Ustyug Chronicle in a Bragin copy of the $13^{\text {th }}-20^{\text {th }}$ senturies] Moscow, Izdanie K. N. Bragina, 1903. 81 p. (In Russian)

9. Zenkova O. B. Troitse-Gledenskii monastyr' [Troitse-Gledensky monastery]. Velikii Ustiug, VUMZ Publ., 2007. 21 p. (In Russian)

10. Akty Kholmogorskoi i Ustiuzhskoi eparkhii. Chast' vtoraia [Acts of the Kholmogorskaia and Ustyugskaia eparchy. Second Part]. St. Petersburg, Russkaia Istoricheskaia biblioteka, 1894. 1286 p. (in Russian)

11. Tikhonov Iu. A. Rynok Ustiuga Velikogo v seredine XVII veka [Market of Veliky Ustyug in the Middle of the $17^{\text {th }}$ century]. Istoricheskie zapiski. Vyp. 39 [Historical notes. Vol.39]. Moscow, AN SSSR Publ., 1952, pp. 204-228. (In Russian)

12. Akty Kholmogorskoi i Ustiuzhskoi eparkhii. Chast' pervaia. 1500-1699 gg. [Acts of the Kholmogorskaia and Ustyugskaia eparchy. First Part. 1500-1699]. St. Petersburg, Russkaia istoricheskaia biblioteka Publ., 1890. $1645 \mathrm{p}$.

13. Mal'tsev N. V. Skul'pturnyi dekor ikonostasov Velikogo Ustiuga [The sculptural iconostas-decoration of Veliky Ustyug]. PKNO. Moscow, Nauka Publ., 1977, pp. 282-295. (In Russian)

14. VUF GAVO. F. 436. Velikoustiugskii Mikhailo-Arkhangel'skii muzhskoi monastyr'. Op. 1. D. 114 [Veliky Ustyug filiation. State Archive of Vologodskaya oblast. Stock 436. Inventory 1. Record 114]. (In Russian)

15. VUF GAVO. F. 363. Velikoustiugskaia dukhovnaia konsistoriia. D. 787. Opis' tserkovnykh predmetov khoziaistvennogo inventaria Troitsko-Gledenskogo monastyria za $1754 \mathrm{~g}$. [Veliky Ustyug filiation. State Archive of Vologodskaya oblast. Stock 363. Record 787].

16. Evdokimov I. V. Sever v istorii russkogo iskusstva [North in the history of Russian art]. Vologda, Soiuz sev. koop. soiuzov Publ., 1921. 230 p. (In Russian)

17. Merzon A.Ts., Tikhonov Iu. A. Rynok Ustiuga Velikogo v period skladyvaniia vserossiiskogo rynka (XVII vek) [Market of Veliky Ustyug in a period of appearance of the global Russian market (17 th sentury]. Moscow, AN SSSR Publ., 1960. 715 p. (In Russian)

18. Dediukhina V.S., Ruzavin Iu. A. Istoriia sozdaniia i restavratsii ikonostasa Troitskogo sobora Gledenskogo monastyria g. Velikogo Ustiuga [History of creation and restoration of the iconostas in the Trinity cathedral of Veliky Ustyug]. Khudozhestvennoe nasledie. Khranenie, issledovanie i restavratsiia. Vyp. 6 (36) [Art heritage. Storage, investigation and restoration. Vol. 6 (36)]. Moscow, Iskusstvo Publ, 1980, pp. 193-202. (In Russian) 
19. Izobrazitel'noe iskusstvo i khudozhestvennaia kul'tura Russkogo Severa kontsa XIV - nachala XXI veka. Novye otkrytiia rossiiskikh restavratorov. Katalog vystavki, posviashchennoi 25-letiiu Vologodskogo filiala VKhNRTs imeni akademika I. E. Grabaria [Figurative art and artistic culture of the Russian North in the end of $14^{\text {th }}$ - beginning of tht 21th sentury. New Discoveries of Russian restorers. Cataloge of the exhibition, devoted to the $25^{\text {th }}$ anniversary of the Vologda branch of Igor Grabar scientific and restoration centre]. Vologda, Arnika Publ., 2012. 152 p. (In Russian)

20. Slovar' russkikh ikonopistsev XI-XVII vekov [Dictionary of Russian icon-painters in the $11^{\text {th }}-17^{\text {th }}$ centuries]. Comp. I. A. Kochetkov. Moscow, Indrik Publ., 2009. 1102 p. (In Russian)

21. Vilinbakhova T. B. Ikona XVI veka «Troitsa v deianiiakh» i ee literaturnaia osnova $\left[16^{\text {th }}\right.$ century Icon "Trinity with its deeds" and its literary source]. TODRL, T. XXXVIII [Transactions of the Ancient Russian Literature Department. Vol.XXXVIII]. Leningrad, Nauka Publ., 1985, pp. 126-137. (In Russian)

22. Nersesian L. V., Komashko N. I. Obraz Troitsy v russkom iskusstve Pozdnego Srednevekov'ia i perekhodnogo vremeni [Image of the Trinity in the art of the Late Russian Middle Ages]. Prepodobnyi Sergii Radonezhskii i obraz Sviatoi Troitsy v drevnerusskom iskusstve. Katalog vystavki [Saint Sergius of Radone$z h$ and the image of Saint Trinity in Russian art. Catalogue of the exhibition. 10 december - 10 february 2014]. Comp. G. V. Popov, N. I. Komashko. Moscow, Krasnaia ploshchad Publ., 2013, pp. 28-35. (In Russian)

23. Vakhrina V.I. Ikony Rostova Velikogo [Icons of Rostov the Great]. Moscow, Severnyi palomnik Publ., 2006. 447 p. (In Russian)

24. Kostromskaia ikona XIII-XIX vekov [Kostroma icon of $13^{\text {th }}-19^{\text {th }}$ centuries]. Comp. N. I. Komashko, S. S. Katkova. Moscow, Grand-Kholding Publ., 2004. 672 p. (In Russian)

25. Rybakov A.A. Vologodskaia ikona. Tsentry khudozhestvennoi kultury zemli Vologodskoi XIIIXVIII vekov [Icon of Vologda. The centers of artistic culture of the Vologda oblast in the $13^{\text {th }}-18^{\text {th }}$ centuries]. Moscow, Galart Publ., 1995. 435 p. (In Russian)

26. Ikona Sviatoi Troitsy tsarskogo izografa Kirilla Ulanova [Saint Trinity Icon by the tsar's izograv Kirill Ulanov]. Ed., compl. I. A. Shalina. Moscow, MRI Publ., 2015. 125 p. (In Russian)

27. Kulikova O. V. Drevnie liki Russkogo Severa. Iz muzeinogo sobraniia ikon XIV-XIX vekov goroda Cherepovtsa [Ancient images of the Russian North. From the museum collection of the $14^{\text {th }}-19^{\text {th }}$ centuries icons in Tserepovets]. Moscow, Grand-Kholding Magma Publ., 2009. 245 p. (In Russian)

28. Iaroslavskii khudozhestvennyi muzei. Katalog sobraniia ikon [Yaroslavl Art Museum. Catalogue of an icon collection]. Compl., author O. V. Kuznetsova, ed. by I. L. Buseva-Davydova. Iaroslavl', Izdatel'skoe biuro «VND», 2012, Vol. II, part 2. 304 p. (In Russian)

29. Pskovskaia ikona XIII-XVI vekov [Pskov icon of the $13^{\text {th }}-16^{\text {th }}$ century]. Compl., author I. S. Rodnikova. Leningrad, Avrora Publ., 1990. 323 p. (In Russian)

30. Dobrynin S.N. Restavratsiia ikony XVII veka «Sviataia Troitsa, so stsenami bytiia» [Restoration of the $17^{\text {th }}$ century icon "Saint Trinity with the scenes of genesis"]. Nasledie Kholmogorskoi zemli XVI nachala XX veka $v$ muzeiakh Arkhangel'skoi oblasti [Heritage of Vologda area 16 - beginning of the $20^{\text {th }}$ century in the museums of the Archangelsk oblast]. Compl., ed. T.M Koltsova. Moscow, SkanRus Publ., 2011, pp. 114-117. (In Russian)

31. Bozhestvennye gimny prepodobnogo Simeona Novogo Bogoslova [Divine hymnes of the saint Simeon the new theologian]. Moscow, Pravilo very Publ., 2006. 718 p. (In Russian)

32. Russkie monastyria. Iskusstvo i traditsiia [Russian monasteries. Art and tradition]. St. Petersburg, Palace Edition, 1997. 239 p. (In Russian)

33. Tel'tevskii P. A. Velikii Ustiug. Arkhitektura i iskusstvo XVII-XIX vekov [Veliky Ustyug. Architecture and art of the $17^{\text {th }}-19^{\text {th }}$ centuries]. Moscow, Iskusstvo Publ., 1977. 179 p. (In Rusian)

34. Briusova V. G. Russkaia zhivopis' XVII veka [Russian painting in the $17^{\text {th }}$ century]. Moscow, Iskusstvo Publ., 1984. 338 p. (In Russian)

35. Danilova I.E., Mneva N.E. Zhivopis' XVII veka [Russian painting in the $17^{\text {th }}$ century]. Istoriia russkogo iskusstva [History of the Russian art]. Ed. by I. E. Grabaria. Moscow, AN SSSR Publ., 1959, vol. IV, pp. 345-466. (In Russian)

36. Bolottseva I.P. Iaroslavskaia ikonopis' vtoroi poloviny XVI-XVII vekov [Icon-painting of Yaroslavl of the second half of the $16^{\text {th }}-17^{\text {th }}$ centuries]. Iaroslavl, Aleksandr Rutman Publ., 2004. 173 p. (In Russian)

37. Kazakevich T.E. Ikonostas tserkvi Il'i Proroka i ego mastera [Iconostas of the St. Elijah church in Yaroslavl and its masters]. Pamiatniki russkoi arkhitektury i monumental'nogo iskusstva [Monuments of the Russian architecture and monumental painting]. Moscow, Nauka, 1980, pp. 13-64. (In Russian)

38. Ikonopistsy tsaria Mikhaila Romanova [The icon-painters of the tsar Mikhail Romanov]. Comp. V.A. Meniailo. Moscow, Khudozhnik i kniga Publ., 2007. 179 p. (In Russian) 
39. Drevlekhranilishche pamiatnikov ikonopisi i tserkovnoi stariny v Russkom muzee. Al'manakh [Archive of Monuments of Russian Icon-painting and Ecclesiastical Art. Anthology]. St. Petersburg, Palace Editions Publ., 2014, issue 433. 208 p. (In Russian)

40. Sviataia Rus'. Al'manakh [Holy Rus. Anthology. Vol. II]. St. Petersburg, Palace Editions Publ., 2011, issue 302.496 p. (In Russian)

41. Ovchinnikova E. S. Tserkov' Troitsy v Nikitnikakh. Pamiatnik zhivopisi i zodchestva XVII veka [The Trinity Church in Nikitniki. Monument of the painting and architecture of XVII century]. Moscow, Iskusstvo Publ., 1970. 196 p. (In Russian)

42. Ikony stroganovskikh votchin XVI-XVII vekov. Po materialam restavratsionnykh rabot VKhNRTs imeni akademika I. E. Grabaria [Icons of the stroganov lands in the 16-17 centuries. By the materials of restoration in the Igor Grabar scientific and restoration centre]. Katalog-al'bom. Moscow, Skanrus Publ., 2003. 439 p. (In Russian)

43. Chugreeva N. N. Kasanskii obraz v proizvedeniiakh stroganovskikh masterov [Kazan image in the work of Stroganov masters]. Kul'turnoe nasledie Russkogo Severa: pamiat' I interpretatsiia. K 90-letiiu Solvychegodskogo istoriko-khudishestvennogo muzeia [Cultural heritage of Russian North: memory and interpretation. On the 90th anniversary of Solvychegodsk Art Historical museum]. St. Petersburg, Pushkinskii Dom Publ., 2009, pp. 92-100. (In Russian)

44. Rossiia. Pravoslavie. Kul'tura. Katalog vystavki. Noiabr' 2000 - fevral' 2001 [Russia. Orthodoxy. Culture. Catalogue of the exhibition. November 2000 - February 2001]. Moscow, OOO "Kollektsiia M" Publ., OAO “Tipografiia Novosti” Publ., 2000. 304 p. (In Russian)

45. Poliakova O. A., Poslykhalina M. V. Podpisnye i datirovannye ikony v sobranii Moskovskogo gosudarstvennogo ob'edinennogo muzeia-zapovednika Kolomenskoe - Izmailovo - Lefortovo - Liublino [Subscribed and dated icons in the collection of the Moskow State Integrated Art and Historical Architectural and Natural Landscape Museum-Reserve]. Moscow, MGOMZ Publ., 2013. 156 p. (In Russian)

46. Meniailo V.A. Ikony Chudova monastyria Moskovskogo Kremlia. Katalog [Icons of the Chudov Monastery in Moskow Kremlin. Catalogue]. Moscow, GMMK Publ., 2015. 483 p. (In Russian)

47. Briusova V. G. Fedor Zubov [Fyodor Zubov]. Moscow, Izobrazitel'noe iskusstvo Publ., 1985. 208 p. (In Russian)

48. Briusova V. G. Neizvestnye proizvedeniia Fedora Zubova [Unknown works of Fyodor Zubov]. PKNO [Cultural monuments. New discoveries], 1979. Leningrad, Nauka Publ., 1980, pp. 256-267. (In Russian)

49. Bolottseva I. P. Novoe o tvorchestve zhivopistsa XVII veka Fedora Evtikhieva Zubova [New materials about a work of the $17^{\text {th }}$ century painter Fyodor Zubov]. GMMK. Materialy $i$ issledovaniia [State Museums of Moskow Kremlin. Materials and researches]. Moscow, Iskusstvo Publ., 1984, pp. 117-132. (In Russian)

50. Buseva-Davydova I. L. Simon Ushakov i russkaia kul'tura vtoroi poloviny XVII veka [Simon Ushakov and Russian culture of the second part of the $17^{\text {th }}$ century]. Simon Ushakov - tsarskii izograf [Simon Ushakov - tzar's painter]. Moscow, GTG Publ., MRI Publ., 2015., pp.10-23. (In Russian)

51. Bekeneva N. G., Nersesian L. V. Simon Ushakov. Zhizn' i tvorchestvo [Simon Ushakov. Life and ouvre]. Simon Ushakov - tsarskii izograf [Simon Ushakov - tsar's painter]. Moscow, GTG Publ., MRI Publ., 2015, pp. 24-39. (In Russian)

52. Komashko N.I. Simon Ushakov i slozhenie novogo stilia russkoi ikonopisi [Simon Ushakov and appearance of a new pictural style]. Simon Ushakov - tsarskii izograf [Simon Ushakov - tsar's painter]. Moscow, GTG Publ., MRI Publ., 2015, pp. 40-51. (In Russian)

53. Ikony iz kollektsii Sergeia Grigorevicha Stroganova [Icons from the Sergey Stroganov's collection]. Authors of the preface T.V.Vilinbakhova, N. V. Pivovarova. St. Petersburg, Palace Edition Publ., 1996. 24 p. (In Russian)

54. RNB. OLDP. F. 88. Siiskii ikonopisnyi podlinnik [Russian National Library. Manuscripts Departement. F. 88. Icon podlinnik of Sia]. (In Russian)

55. Belobrova O. A. K biografii «Gosudareva ikonnika» Fedora Evtikhieva Zubova [About the biography of "gosudar's icon-painter" Fyodor Evtikhiev Zubov]. DRI. Rukopisnaia kniga. Sb. vtoroi [Ancient Russian Art. Old manuscripts. Vol. II]. Moscow, Nauka Publ., 1974, pp. 168-174. (In Russian)

For citation: Zapadalova P.V. "Holy Trinity and Genesis Scenes". Icon from the Troitse-Gledensky Monastery. Vestnik SPbSU. Arts, 2017, vol. 7, issue 2, pp. 168-202. DOI: 10.21638/11701/spbu15.2017.204

Статья поступила в редакцию 19 января 2017 г.; принята в печать 20 марта 2017 г.

Контактная информация

Западалова Полина Вадимовна - кандидат искусствоведения; zapad.dom@mail.ru Zapadalova Polina V. — PhD; zapad.dom@mail.ru 